\title{
Assessing and controlling the risk of cyanobacterial blooms Waterbody conditions
}

Mike Burch, Justin Brookes, and Ingrid Chorus

\section{CONTENTS}

Introduction

8.1 Direct indication of the occurrence of (potentially toxic) cyanobacteria

8.2 Assessing a waterbody's potential for cyanobacterial blooms 508

8.3 Estimating the impact of climate change on cyanobacterial proliferation and blooms

8.4 Internal measures against cyanobacteria: what, why and when? 514

8.5 Hydrophysical control of growth conditions 518

8.5.1 Artificial destratification

8.5.2 Managing river flow regimes to suppress cyanobacterial growth

8.5.3 Managing water retention time in lakes and reservoirs to suppress cyanobacterial growth

8.6 Assessing and controlling internal phosphorus release from the sediments

8.6.1 P reduction by in-lake phosphorus precipitation and capping

8.6.2 P reduction by sediment dredging

8.6.3 Binding phosphorus through hypolimnetic aeration

8.6.4 Withdrawal of $\mathrm{P}$ with the bottom water (hypolimnetic withdrawal)

8.6.5 Reducing the P content of the waterbody by flushing

8.7 Biological control of cyanobacteria

8.7.1 Suppressing cyanobacteria through increasing grazing pressure by fish stock management

8.7.2 Enhancing competition of macrophytes against cyanobacteria

8.8 Introducing barley straw

8.9 Chemical control of cyanobacteria 547

8.9.1 Copper sulphate

8.9.2 Copper chelates 
8.9.3 Hydrogen Peroxide

8.10 Ultrasonication for control of cyanobacteria

8.11 Measures to control the proliferation of benthic cyanobacteria

\section{INTRODUCTION}

While site inspection is highly valuable for assessing the risk of cyanobacterial proliferation or blooms, taken alone this may not be sufficient to assess this risk because of the inherent variability of cyanobacterial occurrence. As explained in Chapter 4, certain waterbody conditions - particularly high levels of phosphorus and high turbidity - are particularly favourable for cyanobacterial growth and enable them to outcompete many planktonic microalgae. An understanding of the growth conditions in the respective waterbody therefore helps to predict whether blooms are likely. It is also a basis for planning measures to control them. Among these measures, the reduction of phosphorus loads from the catchment (Chapter 7) is the method of choice to address the root of the problem, but in some situations, load reduction is not possible to an extent which is sufficiently effective within the required time frame. For such situations, waterbody management options are available to shift growth conditions, making them less favourable for cyanobacterial proliferation. These are termed "internal measures" (in contrast to the management of external nutrient loads to a waterbody). The feasibility of internal measures depends on waterbody characteristics. While Chapter 4 discusses growth conditions from the cyanobacterial perspective, this chapter takes the complementary perspective, focusing on using the assessment of waterbody conditions to estimate the likelihood of cyanobacterial mass development. This includes guidance on estimating whether or not internal measures are both necessary and feasible.

If internal waterbody management measures are to be planned, implemented or validated, a comprehensive knowledge and understanding of the hydrophysical and hydrochemical characteristics of the waterbody as well as of its biota and their interaction (with a focus on phytoplankton ecology) is important as basis for choosing measures that are likely to be successful. This requires involvement of limnological expertise. Where a Water Safety Plan (WSP; see Chapter 6) is developed, it is effective to invite corresponding experts to advise and support the WSP team. Further, particularly where cyanotoxin risks are assessed for the first time, it is valuable to check with waterboards, health inspection and environmental authorities as well as with research institutions in the region whether data from monitoring or research are available, for example, from specific programmes addressing levels of eutrophication, phytoplankton (and specifically cyanobacterial) biomass or cyanotoxin concentrations. Historical data and results from longer-term monitoring, if available, are particularly useful for understanding the cyanobacterial development of a waterbody. 
This chapter intends to support a preliminary assessment of the waterbody situation, to give an overview of measures that may be taken within a waterbody to control cyanobacterial growth and bloom formation, and to give guidance on the questions to address when considering the implementation of internal measures. Sections 8.2-8.11 address different internal control measures that can be implemented alone or in combination, depending on the conditions in the respective waterbody. They provide checklists for assessing the situation and the possible benefits from control measures considered. For each control measure, they also propose options for its operational monitoring, that is, of parameters that indicate failure long before blooms re-appear, and they propose an approach to validating whether the measure is likely to be sufficiently effective.

\section{I DIRECT INDICATION OF THE OCCURRENCE OF (POTENTIALLY TOXIC) CYANOBACTERIA}

For the purpose of hazard assessment, regular monitoring of the occurrence of cyanobacteria or cyanotoxins is most effective if it is focused on waterbodies in which cyanobacteria are likely to occur in quantities potentially relevant to health through the exposure pathways caused by the way these waterbodies are used.

Site inspection is extremely valuable: in contrast to many other chemical and biotic hazards, cyanobacteria are often readily visible if they occur in potentially hazardous concentrations. Site inspection provides information on the overall situation of the waterbody and its surroundings beyond that which can be gleaned from data and documents, including activities and conditions in the vicinity of the waterbody. Site inspection may miss bloom situations, particularly if it occurs at long time intervals (i.e., greater than weekly), but such observations may be available from authorities (waterboards, health inspection, environmental authorities), from members of the local community ("citizen scientists"; see Chapters 11 and 15), operators of campsites, boat rental operators, restaurants and from scientific organisations conducting research on the waterbody. Asking these stakeholders to report the occurrence of surface streaks, scums, pronounced greenish or reddish discoloration or greenish turbidity may help to identify circumstances for further investigation.

A range of instruments and sensors, in particular fluorescence probes, allow real-time monitoring of cyanobacteria and algae for management purposes, as does remote sensing (see Chapter 13). Water utilities increasingly employ water quality monitoring systems with probes that measure temperature, conductivity, dissolved oxygen profiles, etc., together with fluorescence of chlorophyll and that of accessory pigments to monitor phytoplankton distribution and/or concentrations at raw water intakes. However, along with the opportunities given through these in situ fluorometers, it is 
important to be aware of uncertainties and technical limitations of this potentially complex technology (see Chapter 13, Zamyadi et al., 2016, and Bertone et al., 2018).

Checklist 8.1 is intended as a template for questions to address in preparation of site inspection and to ask residents of the area and local stakeholders during site inspection.

\section{CHECKLIST 8.I: ASSESSING DIRECT INDICATION OF THE OCCURRENCE OF (POTENTIALLY TOXIC) CYANOBACTERIA}

- Have scums been observed? (Note: sometimes duckweed is taken for cyanobacterial scum, so ask whether individual tiny plants of a few $\mathrm{mm}$ diameter were recognisable - this is likely to be duckweed, i.e., Lemna minor.)

- Has conspicuous colour (greenish or wine-red) been observed with low transparency (i.e., $<1 \mathrm{~m}$ )?

- Has the water been investigated for the occurrence of cyanobacteria? If so, were any quantitative data obtained? If so, do they include biovolumes $>0.3-1 \mathrm{~mm}^{3} / \mathrm{L}$ or concentrations of chlorophyll- $a$ (during dominance of cyanobacteria) $>1 \mu \mathrm{g} / \mathrm{L}$ ?

- Have cyanotoxins ever been detected? If so, at what concentrations?

- Are there any reports of animal or even human illness associated with exposure to blooms? (Note: while a clear association of human symptoms with cyanobacteria is not very likely, such concern may well have been voiced.)

\subsection{ASSESSING A WATERBODY'S POTENTIAL FOR CYANOBACTERIAL BLOOMS}

The key prerequisite for a high biomass density of any phytoplankton, including cyanobacteria, is elevated concentration of nutrients. In most cases, the concentration of total phosphorus (TP) can be used to estimate the potential of bloom development in a waterbody (i.e., the "carrying capacity"): in general, high concentrations of phytoplankton biomass - typically dominated by cyanobacterial blooms - occur at TP concentrations above $20-50 \mu \mathrm{g} / \mathrm{L}$, depending on hydrophysical conditions of the waterbody, particularly mixing depth (see section 4.3).

Exceptions to this widespread pattern include some very large deep lakes and reservoirs which develop thin and transient surface scums even at TP 
concentrations in the range of $10-20 \mu \mathrm{g} / \mathrm{L}$, and while these can support only a low cyanobacterial cell density and biomass, scums are nevertheless possible because they can be recruited out of a large volume of water. Figure 4.6 in Chapter 4 illustrates how this can concentrate toxins by several orders of magnitude. Also, metalimnetic populations of Planktothrix rubescens, typical for deep, stably stratified mesotrophic waterbodies, may be relevant for human exposure if drinking-water is abstracted from that level. They typically stay at depth until autumn or winter when mixing entrains them throughout the waterbody and up to the surface where they then can form significant and spectacular surface blooms which may pose a potential toxin hazard (see Boscaini et al. (2017) for an example). Benthic cyanobacteria are a further exception as these typically occur in very clear, shallow water with low nutrient concentrations (section 4.2.2); however, while they result in high toxin concentrations in detached mats or agglomerations of macrophyte material, they are not known to cause high concentrations in the water.

If the concentration of TP in a given waterbody can be sufficiently controlled in order to suppress cyanobacterial dominance and biomass, excessive nitrogen concentrations will not be relevant for cyanotoxin occurrence. However, where reaching this target is not feasible, for certain periods of the seasonal cycle or year-round, assessing whether nitrogen is limiting may be relevant. This is most likely in mesotrophic and eutrophic shallow lakes which can be N-limited during summer if organic substance on the sediment surface and high temperatures promote denitrification. While low $\mathrm{N}$ concentrations have been proposed to risk shifting cyanobacterial species composition to those that can fix atmospheric nitrogen, field data show this to rarely be the case because nitrogen fixation requires high amounts of light energy which are usually not available in turbid eutrophic waterbodies. Nitrogen limitation can be assumed at concentrations of dissolved inorganic $\mathrm{N}$ below $100 \mu \mathrm{g} / \mathrm{L}$ (see section 4.2.1 and Kolzau et al., 2014.). While there are methods to reduce phosphorus cycling within a waterbody discussed below, for nitrogen the only options for reduction are natural denitrification and to control nitrogen loading to the waterbody (see Chapter 7; for a broader discussion of the role of $\mathrm{N}$ see Chorus and Spijkerman, 2020).

While a high concentration of total phosphorus (TP) and TN (total nitrogen) is a prerequisite for high cyanobacterial biovolumes, this is not the only one.

A low water exchange rate is usually a further condition for bloom formation. Given that cyanobacteria grow rather slowly, they need sufficient residence time in the waterbody to establish large populations - often in the range of weeks. High river flows will dilute and wash out cyanobacteria faster than they can grow, and blooms are unlikely in lakes and reservoirs with water retention times of less than one month. For temperate climate 
settings, a further consequence of low growth rates is that it often takes till late summer for cyanobacteria to outcompete the more rapidly growing springtime algal phytoplankton and become dominant; that is, the typical "cyanobacterial season" is from mid-summer to (late) autumn. Exceptions include the non-scum-forming Limnothrix spp., often associated with other fine filamentous cyanobacteria and or Planktothrix agardhii; these may occur with high biomass in summer, particularly if they survive in winter and dominate already in spring.

Low water transparency is often a further condition linked to the dominance of a range of cyanobacterial species, not because it is a precondition for their growth, but because it is a consequence of bloom occurrence. Also, for some cyanobacterial species, this may function as positive feedback loop: for those that grow well at rather low light intensity (better than many phytoplanktonic algae), the likelihood of their dominance is higher in turbid water (Table 8.1).

Table 8.I Conditions affecting or indicating the likelihood of high cyanobacterial biomass (see section 5.3 for references)

\begin{tabular}{|c|c|c|c|c|}
\hline $\begin{array}{c}\text { Total } \\
\text { phosphorus }\end{array}$ & \multicolumn{2}{|c|}{ Mixing conditions } & Transparency & $\mathrm{pH}$ \\
\hline$>50 \mu g / L$ & $\begin{array}{l}\text { Stagnant, depth } \\
>5-10 \mathrm{~m} \text {, with } \\
\text { stable thermal } \\
\text { gradients: } \\
\text { Favours } \\
\text { scum-forming } \\
\text { taxa, i.e., } \\
\text { Microcystis, } \\
\text { Dolichospermum, } \\
\text { Aphanizomenon }\end{array}$ & $\begin{array}{l}\text { Stagnant, } \\
\text { shallow and } \\
\text { well mixed: } \\
\text { Favours } \\
\text { non-scum } \\
\text { forming } \\
\text { taxa, i.e., } \\
\text { Planktothrix } \\
\text { agardhii and } \\
\text { other fine } \\
\text { filamentous } \\
\text { forms, e.g., } \\
\text { Limnothrix }\end{array}$ & $\begin{array}{l}\text { Low; } \\
\text { Secchi depth } \\
\text { often }<1 \text { m }\end{array}$ & $\begin{array}{l}\mathrm{pH}>7 \\
\text { (often }>8 \text { or } \\
\text { possibly }>9 \\
\text { due to high } \\
\text { rates of } \\
\text { photosynthesis } \\
\text { associated } \\
\text { with high } \\
\text { biomass) }\end{array}$ \\
\hline $\begin{array}{c}20-50 \\
\mu g / L\end{array}$ & \multicolumn{2}{|c|}{$\begin{array}{l}\text { Stagnant, deeper than } 10 \mathrm{~m} \text {, } \\
\text { stratified: potential for mass } \\
\text { development of Planktothrix } \\
\text { rubescens which accumulates } \\
\text { at the metalimnion }\end{array}$} & $\begin{array}{l}\text { Moderate; } \\
\text { Secchi depth } \\
\sim 1-3 \mathrm{~m}\end{array}$ & $\mathrm{pH} \geq 7$ \\
\hline $\begin{array}{c}10-20 \\
\mu g / L\end{array}$ & Fast flowing river & \multirow{2}{*}{$\begin{array}{l}\text { Lake or } \\
\text { reservoir } \\
\text { with water } \\
\text { residence } \\
\text { time }<1 \\
\text { month }\end{array}$} & $\begin{array}{l}\text { High; } \\
\text { Secchi depth } \\
\sim 3-7 \mathrm{~m}\end{array}$ & $\mathrm{pH} 6-7$ \\
\hline$\leq 10 \mu g / L$ & $\begin{array}{l}\text { Mountain stream } \\
\text { or brook }\end{array}$ & & $\begin{array}{l}\text { Very High } \\
\text { - Clear } \\
\text { water; } \\
\text { Secchi depth } \\
\text { often }>7 \mathrm{~m}\end{array}$ & $\mathrm{pH}<6$ \\
\hline & \multicolumn{4}{|c|}{ Exception: mats of cyanobacteria attached to surfaces } \\
\hline
\end{tabular}


Waterbody mixing is well tolerated by many cyanobacteria because of their tolerance of low light availability, as mixing entrains cells into deeper, low-light layers. Cyanobacterial taxa with tolerance of low light intensity are widespread in relatively shallow, well-mixed waterbodies. Deep mixing of a waterbody can, however, suppress the proliferation of scum-forming cyanobacteria such as Microcystis spp. and Dolichospermum spp.: these cyanobacteria are less effective competitors for light, and they compensate for this by regulating their buoyancy and thus their vertical position in the waterbody (see section 4.3). If they are entrained by deep and sufficiently strong mixing, they lose this competitive advantage.

High temperature is often assumed to enhance cyanobacterial growth. As discussed in section 4.4.2, this may chiefly act indirectly through the stabilisation of thermal stratification. Thus, high temperature may be an indicator for the increased likelihood of cyanobacterial blooms.

A further indicator is high $\mathrm{pH}$. It is well established that cyanobacteria are rarely found at levels that represent a health hazard if $\mathrm{pH}$ is $<6-7$ (note that high $\mathrm{pH}$ is not a cause, but rather a consequence of high phytoplankton biomass, often due to cyanobacterial blooms (section 4.3.6 and Tables 8.1 and 4.2); nonetheless, high $\mathrm{pH}$ indicates that blooms may be occurring).

In summary, cyanobacteria are likely to occur at concentrations that represent a health hazard for periods longer than a few days if the waterbody meets most of the conditions in Checklist 8.2.

\section{CHECKLIST 8.2: ASSESSING WHETHER WATERBODY CONDITIONS FAVOUR CYANOBACTERIAL GROWTH AND PROLIFERATION, LEADING TO THE OCCURRENCE OF BLOOMS}

- Is the waterbody eutrophic, that is, are concentrations of TP $>20-50$ $\mu \mathrm{g} / \mathrm{L}$ and those of $\mathrm{TN}$ about 10 -fold higher?

- If yes, are concentrations of dissolved inorganic phosphorus detectable (that is, above $5-10 \mu \mathrm{g} / \mathrm{L}$ ) and those of inorganic nitrogen above $100 \mu \mathrm{g} / \mathrm{L}$ ?

- Is the water retention time > one month?

- If transparency is low, is this due to phytoplankton (and not to suspended minerals), that is, are Secchi disc readings $<1-2 \mathrm{~m}$ (during the bloom season)?

- Is the waterbody either shallow and well mixed or deep with stable thermal stratification?

- Is the water alkaline rather than acidic, that is, $\mathrm{pH}>7$ ?

- For temperate climates, is the season late summer and early autumn?

- For rivers, are there tributaries that import blooms (e.g., from impoundments in which they may develop)? 
If a waterbody meets all of these conditions, this does not mean that cyanobacterial blooms will necessarily occur - it merely indicates an elevated likelihood of their occurrence. Vice versa, if it does not meet these conditions, cyanotoxin concentrations exceeding the guideline levels discussed in Chapter 2 are not likely but they cannot be totally excluded - for example, from metalimnetic maxima entering a drinking-water offtake (Chapter 9) or from detached benthic cyanobacteria.

\subsection{ESTIMATING THE IMPACT OF CLIMATE CHANGE ON CYANOBACTERIAL PROLIFERATION AND BLOOMS}

As discussed in section 4.5, understanding how climate warming will affect cyanobacteria is far more complex than the direct impact of higher water temperature (by, e.g., 2-3 degrees Celsius) on their growth rate: rather, it requires an understanding of the shifts in the aquatic ecosystem's functioning that may occur and how such shifts affect the dominance of cyanobacteria relative to that of other species. This includes changes in duration of thermal stratification, ice cover and patterns of drought versus heavy rainfall, all of which in turn can have significant impacts on waterbody mixing patterns, water levels, oxygen concentrations, nutrient loads and concentrations, and fish and zooplankton populations (section 4.5 and overviews by Moss et al., 2011; Winder \& Sommer, 2012, and Hamilton et al., 2016).

Whether climate change will enhance cyanobacterial proliferation in a specific waterbody depends on which way the impacts of warming and the associated changes in the aquatic ecosystem will interact - resulting in a potential increase or decrease in the dominance and biomass of cyanobacteria. For example, while warmer weather and the resulting increased stability of thermal stratification may favour cyanobacteria blooms, reduced mixing may also reduce the nutrient supply from deeper layers to upper layers where cyanobacteria can grow (Salmaso et al., 2018). Less runoff in dry warm periods may also work both ways, decreasing or increasing phosphorus input with the corresponding impact on the biomass of cyanobacteria that may develop.

Predicting the potential impacts of climate change on cyanobacteria in a given waterbody requires assessing locally how climate changes are most likely to impact on the conditions listed in Table 8.2. While this list incorporates our conventional understanding of cyanobacterial ecology and the drivers for cyanobacterial growth, using these categories for predicting whether blooms will increase or decrease involves considerable uncertainty, particularly for the hydrological drivers of bloom development. Uncertainty 
Table 8.2 Possible effects of global warming that can increase or decrease cyanobacteria

Impacts of global warming that can

\begin{tabular}{|c|c|}
\hline Increase cyanobacteria & Decrease cyanobacteria \\
\hline $\begin{array}{l}\text { In waterbodies with higher trophic state, } \\
\text { higher temperature may increase } \\
\text { nutrient release from sediments, fertilising } \\
\text { growth, particularly in nonstratifying } \\
\text { waterbodies where these nutrients reach } \\
\text { the upper water layers }\end{array}$ & $\begin{array}{l}\text { Higher temperature may lead to more } \\
\text { stable thermal stratification, thus } \\
\text { reducing nutrient transport from deep } \\
\text { water layers into upper layers where } \\
\text { they would fertilise growth (relevant in } \\
\text { waterbodies in which biomass in the } \\
\text { surface layers is nutrient limited) }\end{array}$ \\
\hline $\begin{array}{l}\text { More frequent storms can reduce } \\
\text { thermal stratification, thus transporting } \\
\text { nutrient-rich water from deeper layers } \\
\text { into upper layers where it fertilises growth }\end{array}$ & $\begin{array}{l}\text { More frequent storms can disrupt } \\
\text { cyanobacterial blooms, giving other taxa } \\
\text { a chance to outcompete them after the } \\
\text { storm }\end{array}$ \\
\hline $\begin{array}{l}\text { Stronger and/or more frequent } \\
\text { storms can increase flow and thus } \\
\text { nutrient loads }\end{array}$ & $\begin{array}{l}\text { Stronger and/or more frequent } \\
\text { storms can increase flow and thus } \\
\text { water exchange rates, potentially } \\
\text { carrying cyanobacteria out of the system }\end{array}$ \\
\hline $\begin{array}{l}\text { Longer periods of drought reduce } \\
\text { water exchange rates; thus there is less } \\
\text { dilution of nutrient discharges to the } \\
\text { waterbody, increasing concentrations and } \\
\text { fertilising cyanobacteria }\end{array}$ & $\begin{array}{l}\text { Longer periods of drought reduce } \\
\text { inflow and thus nutrient loads from } \\
\text { erosion and other diffuse sources in the } \\
\text { catchment, potentially limiting } \\
\text { cyanobacterial biomass }\end{array}$ \\
\hline \multicolumn{2}{|l|}{$\begin{array}{l}\text { Longer periods of drought reduce } \\
\text { water exchange rates, allowing blooms to } \\
\text { last longer }\end{array}$} \\
\hline \multicolumn{2}{|l|}{$\begin{array}{l}\text { Longer periods of drought can reduce } \\
\text { water levels in stratified reservoirs to } \\
\text { where no "clean" layer without blooms is } \\
\text { available to abstract drinking-water }\end{array}$} \\
\hline \multicolumn{2}{|l|}{$\begin{array}{l}\text { Longer periods of drought can reduce } \\
\text { water levels in stratified reservoirs and } \\
\text { lead to warmer water over the sediment. } \\
\text { As a result, more phosphorus is released } \\
\text { from the sediment }\end{array}$} \\
\hline \multicolumn{2}{|l|}{$\begin{array}{l}\text { Longer periods of stable thermal } \\
\text { stratification can give cyanobacterial } \\
\text { dominance more time to form and to last, } \\
\text { thus increasing the duration of the season } \\
\text { with toxic cyanobacteria }\end{array}$} \\
\hline $\begin{array}{l}\text { In lakes with higher trophic state, anoxia } \\
\text { above the sediments and redox-sensitively } \\
\text { bound phosphorus, longer periods of } \\
\text { stable thermal stratification can } \\
\text { enhance the consumption of oxygen in } \\
\text { the deep water, leading to more release of } \\
\text { phosphorus from the sediment }\end{array}$ & \\
\hline
\end{tabular}


is lower regarding the impact of nutrient concentrations because these set clear limits: if concentrations are too low to support a substantial planktonic biomass, it cannot develop even as water gets warmer or stratification more stable (see discussion in section 4.5).

Prediction for a given waterbody therefore requires a comprehensive understanding of local conditions as well as expertise in hydrology, limnology and possibly in modelling phytoplankton occurrence (see section 4.4.1).

\subsection{INTERNAL MEASURES AGAINST CYANOBACTERIA: WHAT, WHY AND WHEN?}

The experience across the globe of several decades of lake and reservoir restoration - that is, reversing eutrophication - shows that the benefit of internal measures mostly lies in speeding up the ecosystem response once external nutrient loads have been significantly reduced. Internal measures are rarely successful if external loads of nutrients, particularly phosphorus, remain high. There are, however, settings in which cyanobacteria are a problem requiring a rapid solution while sufficient reduction of external loads is unlikely to be rapidly feasible or sufficiently effective to solve the problem. Lowland stretches of trans-boundary rivers are a typical example: some are naturally eutrophic. Also, typically many stakeholders in the catchment may need to engage in nutrient control. It takes time to establish an effective policy in catchment management to reduce river phosphorus concentrations to sufficiently low levels along the entire river reach. Some internal measures can work in such situations, but they need to be continuously or repeatedly applied until the external load will have been sufficiently reduced.

In other situations, external load reduction may be effective, but internal phosphorus loads, released from sediments, are high and will sustain cyanobacterial biomass above target levels for quite some time. Particularly in lakes with very low flushing rates, the phosphorus supply in the lake may remain high for many years, even after substantial load reduction. In such settings, internal measures may give the ecosystem a kick to interrupt the prevalent ecosystem feedback mechanisms that stabilise the eutrophic or hypertrophic situation. Such measures can target a transition in sediment chemistry to reduce phosphorus release rates from the sediment (section 8.7) or they can target other conditions to make them less favourable for cyanobacteria, for example,

i. by suppressing the dominance of cyanobacteria in favour of other (nontoxic, non-scum-forming) phytoplankton species and - in lakes with substantial shallow areas - of aquatic macrophytes;

ii. by increasing loss rates of the cyanobacterial populations. 
Table 8.3 gives an overview of internal measures.

Monitoring the system's response to an internal measure is important to assess whether the measure needs to be repeated or whether the system self-stabilises with a less eutrophic biotic community structure in which cyanobacteria only play a minor role.

The most important first step in planning is to make sure that internal measures are necessary. Two reasons can stand against this: (i) it may be more sustainable and effective to invest in reduction of external nutrient loads, and this needs to have been sufficiently explored before deciding to invest in internal measures, and (ii) external load reductions may already be leading to a decline in internal phosphorus concentrations, and it is worthwhile monitoring this decline to see if it will be sufficient to reach target phosphorus concentrations within the necessary time span.

Time lags between the reduction of external nutrient loads and the desired results achieved in the waterbody may be substantial, that is, in the range of a decade, and response times strongly depend on water exchange rates. Resilience effects are not uncommon, even after substantial reduction of inputs below thresholds calculated to be effective. Sas (1989) discusses two (partially connected) resilience mechanisms

Table 8.3 Overview of measures to suppress cyanobacterial growth by influencing internal waterbody processes

\begin{tabular}{|c|c|c|}
\hline Intervention target & Intervention type & Technique \\
\hline $\begin{array}{l}\text { Suppress dominance of } \\
\text { cyanobacteria, potentially } \\
\text { in favour of other } \\
\text { phytoplankton }\end{array}$ & $\begin{array}{l}\text { Hydrophysical } \\
\text { control of growth } \\
\text { conditions }\end{array}$ & $\begin{array}{l}\text { Mixing - artificial destratification } \\
\text { Decreasing water retention time } \\
\text { Maintaining sufficient flow and thus } \\
\text { a rapid change of hydrophysical } \\
\text { conditions, that is, avoiding or } \\
\text { removing impoundments }\end{array}$ \\
\hline $\begin{array}{l}\text { Suppress internal } \\
\text { phosphorus }(P) \text { load } \\
\text { released from the sediment } \\
\text { Note: this is only likely to be } \\
\text { successful if sediments are } \\
\text { a major } P \text { source relative } \\
\text { to the external P load }\end{array}$ & $\begin{array}{l}\text { Internal phosphorus } \\
\text { control }\end{array}$ & $\begin{array}{l}\text { Sediment removal } \\
\text { Sediment treatment with P-binding } \\
\text { agents, for example, lime, alum, } \\
\text { modified clay, zeolite } \\
\text { Suppressing redox-sensitive P } \\
\text { release by oxidising the sediment } \\
\text { surface (through hypolimnetic } \\
\text { aeration or oxygenation) }\end{array}$ \\
\hline $\begin{array}{l}\text { Enhance loss rates of } \\
\text { phytoplankton, including } \\
\text { cyanobacteria, or support } \\
\text { their competitors }\end{array}$ & Biological control & $\begin{array}{l}\text { Biomanipulation } \\
\text { Barley straw } \\
\text { Viruses, bacteria }\end{array}$ \\
\hline $\begin{array}{l}\text { Induce rapid lysis of } \\
\text { cyanobacterial cells or } \\
\text { inhibition of their growth }\end{array}$ & Chemical control & Algicides, algistats \\
\hline
\end{tabular}


for phosphorus concentrations: (i) a delayed response of in-lake total phosphorus (TP) concentrations to a reduction of input, due to the time required for flushing phosphorus out of the waterbody, and (ii) phosphorus release from the sediments ("internal loading") until a new sedimentwater equilibrium is established.

Additionally, as mentioned above, the community structure of the organisms in a waterbody may show resilience to change - through several mechanisms. For many shallow mesotrophic to slightly eutrophic lakes, two alternate states are possible at the same external nutrient load: either clear water due to dominance of macrophytes (i.e., submersed aquatic plants and reed belts) or turbid water due to dominance of phytoplankton, often cyanobacteria (Scheffer et al., 1993; Scheffer et al., 1997). Once phytoplankton dominates at high density, this causes turbidity which shades the macrophytes to the extent where they are unable to grow, and thus, phytoplankton dominance self-stabilises. Such a lake can be returned to the clear water macrophyte-dominated state if nutrient concentrations can be reduced to the point where phytoplankton are nutrient-limited and thus less dense; the water therefore becomes clearer and the previously light-limited macrophytes are then able to ecolonize.

Also, phytoplankton species composition may resist change: once high cell densities of cyanobacteria are established in a waterbody, some of these will survive, for example, on the sediment surface even when conditions become less favourable (e.g., during winter), and these cells are available as inoculum to seed the population in the next growing season. Furthermore, fish populations affect zooplankton populations, which in turn feed on phytoplankton, thus affecting its species-specific loss rates, and such food-chain mechanisms can cause resilience to change or be manipulated to enhance change (e.g., through fish stock management; see below). Nature may overcome such biological resilience phenomena by itself with time, but change can be accelerated by the interventions described below.

Waterbody ecosystem processes are highly complex and quite specific to an individual waterbody (Chapter 4). Consequently, predictions of their response to interventions have a higher uncertainty than predictions of responses to measures in most technical systems (e.g., drinking-water treatment). A prerequisite for success of internal measures is that they are planned on the basis of comprehensive understanding of the waterbody ecosystem - of its hydrological regime, its biota and its sediment chemistry (see Checklist 8.3). Involving limnology experts in planning and designing such measures is therefore fundamental for success. Additionally, expert review of the plans as well as later validation of the measures taken (preferably by experts independent of those contracted for planning and implementing the measure) is important to understand factors leading to success or failure, 
and if necessary, to readjust measures. Neglecting the need to understand the individual waterbody for planning, validating and adjusting internal measures risks failed investments. The data to collect should cover at least one growing season.

\section{CHECKLIST 8.3: ASSESSING THE POTENTIAL BENEFITS AND THE PROSPECT OF SUCCESS OF IMPLEMENTING AN INTERNAL MEASURE}

- Before planning any specific internal measure, answering the following questions will help to clarify whether or not to take an internal measure at all, and if so, to decide on which option(s) would be best for the given waterbody:

- Is an internal measure necessary because

- the external phosphorus (P) load cannot be sufficiently (quickly) reduced?

- the waterbody ecosystem is responding slower than necessary to the external load reduction?

- no alternative water sources are available for an important use of the waterbody, making rapid improvement necessary?

- the fraction of internal phosphorus loading from the sediments is high in relation to external loads and will likely stay high for many years or even decades?

- What exactly should the internal measure target - a suppression of cyanobacterial dominance within the phytoplankton, a shift from phytoplankton to macrophytes (in shallow lakes), a reduction of internal phosphorus loading or an increase of overall phytoplankton loss rates and thus a decrease of biomass - including that of the cyanobacteria?

- Is the internal measure needed once (maybe with one repeat) to help to overcome ecosystem resilience and trigger the waterbody's shift to a lower trophic state, or will it be needed continuously because external $P$ loads remain too high?

- Are investment and operation costs adequate in relation to the waterbody's priority for human use and/or environmental targets?

- Is the necessary expertise available for this decision, that is, for planning the measure in more detail and for monitoring success?

- Is the necessary data and information on P sources and trends available to make a decision on the most effective approach, and is capacity available to monitor the response of the waterbody? 


\subsection{HYDROPHYSICAL CONTROL OF GROWTH CONDITIONS}

Thermal stratification of a waterbody influences the depth at which cyanobacteria occur and the amount of light they receive. It may also affect the nutrient concentrations available in the upper layers in which there is enough light for growth (section 4.3.3). Water exchange rates determine whether cyanobacterial populations are diluted faster than they can grow. Changing hydrophysical conditions, for example, through impoundment, may suddenly turn a waterbody previously scarcely affected by cyanobacteria into one with heavy blooms. Vice versa, some hydrophysical measures may specifically reduce cyanobacterial growth, allowing other phytoplankton species (planktonic microalgae) to become dominant. Given that freshwater phytoplankton species other than cyanobacteria are not known to be toxic, they may be less of a problem, particularly for nonpotable water use.

A caveat with all hydrophysical control approaches is that if nutrient levels remain high enough to support substantial amounts of phytoplankton biomass (i.e., $>20-50 \mu \mathrm{g} / \mathrm{L}$ total phosphorus (TP) and $>100-150 \mu \mathrm{g} / \mathrm{L}$ dissolved nitrogen; see section 4.3), their success in suppressing cyanobacterial biomass can be somewhat uncertain. Also, other phytoplankton, that is, eukaryotic algae, may continue to reach substantial levels of biomass which can cause problems, for example, challenge drinking-water treatment with organic matter. Thus, depending on the specific circumstances, hydrophysical measures may not be sufficient to achieve water quality targets if overall phytoplankton biomass remains high even if they succeed in suppressing cyanobacteria.

Because of the inherent uncertainty involved in the manipulation of complex biological interactions, for hydrophysical interventions validation is particularly important, that is, checking whether the measure chosen proves effective for suppressing cyanobacterial blooms. As discussed above, this will require observing whether cyanobacterial blooms still occur - preferably for several growing seasons (see Chapters 11-13).

\subsection{Artificial destratification}

While artificial mixing or circulation is one of the most commonly recommended and employed management interventions to attempt to reduce the growth of cyanobacteria in lakes and reservoirs, it requires continuous operation, involving costs for energy and maintenance. Chances of success depend very much on a thorough prior baseline assessment of the conditions in the specific waterbody: it will not work in every case.

Its application is based upon the aim to eliminate the stratification in the system and affect the balance of growth between different species of phytoplankton, including cyanobacteria, by changing the physical conditions in the waterbody and thereby leading to a change in the phytoplankton 
composition and/or biomass. This is specifically based on the fact that the composition of the phytoplankton community in hypertrophic and eutrophic systems is often strongly driven by competition for light, and light availability is impacted by waterbody mixing and the vertical distribution of phytoplankton cells (Huisman et al., 2004). A comprehensive review of artificial mixing explains this: Visser et al. (2016) examined the mechanism of action of mixing upon the phytoplankton community. Artificial mixing works through increasing mixing depth, which affects the competition between cyanobacteria and eukaryotic algae in two ways. Firstly, mixing reduces the sedimentation losses of phytoplanktonic algae which are not buoyant (e.g., green algae and diatoms), and hence, their net growth rates tend to increase. Secondly, the buoyant cyanobacteria with a tendency to float are entrained into the deep, artificially induced turbulence and experience a lower light dose and stronger light fluctuations, and hence, their net growth rate tends to decrease. Based upon these principles, artificial mixing has been applied with the aim to disrupt the suitability of stable growth conditions favourable for cyanobacteria and prevent buoyant cyanobacteria from forming scums.

Visser et al. (2016) also reviewed the evidence from an extensive number of studies of mixing as to their success or failure to draw conclusions about possible reasons for this. They concluded that artificial mixing was not successful if the system was: (i) not sufficiently well mixed vertically, (ii) too shallow or (iii) if the horizontal distribution and position of mixing devices was not adequate to cover the entire lake to induce turbulent flow fully across the lake. If the mixing rate is not high enough to entrain the cyanobacteria and decrease their light exposure, buoyant colony-forming cyanobacteria can "escape" from the turbulent flow due to their high flotation velocity. In addition, artificial mixing will generally only be effective in relatively deep lakes. Their review of studies resulted in a minimum depth of $>15 \mathrm{~m}$ at which mixing was successful to control Microcystis, which has a high flotation velocity; however, mixing depth could be less and mixing could work in shallower lakes for other cyanobacteria such as filamentous types which have a much lower flotation velocity (e.g., Planktothrix spp.).

Other studies have shown that artificial destratification has been successful in a number of cases with less critical examination of the principles (Reynolds et al., 1983; Hawkins \& Griffiths, 1993; Heo \& Kim, 2004; Lewis, 2004; Becker et al., 2006), or less successful at controlling cyanobacteria while effectively controlling other problems such as the release of iron, manganese and nutrients from sediments by maintaining oxidising conditions (McAuliffe \& Rosich, 1989). The reasons for lack of success are typically not well documented; however, it most likely relates to insufficient mixing to counteract the effect of surface heating causing the formation of a warm surface layer which favours cyanobacteria. It is important to 
recognise that artificial mixing and destratification may not be practical and feasible in very large and very deep lakes.

A number of techniques have been proposed to directly disrupt the thermal stratification of a waterbody, including aeration systems, mechanical devices (like pumps) and solar-powered water mixers (Visser et al., 2016). Hydrodynamic modelling by Antenucci et al. (2003) suggests that for aeration systems, a combination of a deep diffuser to disturb the seasonal thermocline and a shallow diffuser to enhance vertical mixing of the epilimnion could be more effective. Surface-mounted mechanical mixers proved effective at promoting circulation and improving dissolved oxygen concentrations but not more successful than bubble plume aerators, and they have higher maintenance costs (Lewis, 2004). For solar-powered upflow, water circulators Upadhyay et al. (2013) found that these mixers tend to circulate only the epilimnetic water and stratification is maintained; thus, these mixers have a limited zone of influence and are unable to adequately mix entire lakes to effectively control cyanobacteria.

The most common and effective destratification devices are bubble plume aerators. They require a compressor to pump air to a diffuser line in the reservoir. They work by releasing a series of fine air bubbles from a pipe or line near the bottom of the lake. As the bubbles rise, they entrain water from different depths into a plume. When the plume reaches the surface, the air dissipates and the plume plunges to a depth of equivalent density and moves through the reservoir as an intrusion. Return currents flow on each side of the intrusion and generate basin-scale circulation (Schladow, 1993; Whittington et al., 2000).

Often, some stratification will still be evident outside of the immediate influence of the aerator (Sherman et al., 2000), and while this stratification is weaker than without mixing, cyanobacterial cells near the surface may not be entrained (Visser et al., 1996). This means there is still a habitat for buoyant cyanobacteria to exploit (Sherman et al., 2000). In warm climates and where night-time temperatures are high, cyanobacterial growth may still be observed in artificially destratified reservoirs, for example, in Chaffey Dam, Tamworth Australia (Sherman et al., 2000), and in North Pine Dam, Queensland Australia (Burford \& O’Donohue, 2006).

Many mixing and circulating systems are available commercially and are actively marketed. Engineering expertise is sufficiently developed to design systems that can meet the specific local mixing requirements. Care must be taken, however, to engage competent companies and to plan the management and ecological targets set in combating cyanobacterial blooms. Particularly in tropical and subtropical countries with high and prolonged insolation, the energy costs of systems to maintain mixing can be significant. Poorly designed aerators may transport nutrients from sediment-near layers to the epilimnion without reducing stratification sufficiently to meet the targets, and this will favour the growth of cyanobacteria (Tsujimura, 2004). Given the initial capital expenditure and the ongoing energy and maintenance 
costs, it is important to properly size the aerator. Hydrodynamic modelling is recommended to predict the likely changes in the stability of stratification, potentially refining the aerator design in response to the results. A design methodology for the design of aerators for destratification of lakes is given by Schladow (1993).

Four notes of warning need to be considered when considering and planning destratification:

1. In some (primarily shallower and naturally weakly stratified) lakes, artificial destratification may promote the growth of cyanobacteria that are favoured by mixed conditions such as Planktothrix agardhii, Planktothrix rubescens or Raphidiopsis (Cylindrospermopsis) raciborskii (see section 4.2.1).

2. Artificial destratification may not only increase $P$ concentrations in the epilimnion as discussed above. It will also increase temperatures above the sediment and thus biodegradation rates of organic matter, which further increases $P$ release (see section 8.3.4). If phosphorus is the limiting nutrient, this could increase overall phytoplankton biomass, particularly that of cyanobacteria.

3. Mixing of mesotrophic and otherwise stably stratified lakes can induce growth and entrainment of Planktothrix rubescens during autumn or winter and in spring (Nürnberg et al., 2003).

4. Drinking-water is preferably extracted from deeper, cooler water layers (to reduce microbial growth in the distribution network), and artificial mixing of deep waterbodies causes warming of that water layer.

Aerators can have additional benefits or primary uses other than controlling cyanobacteria. They have also been proposed as mechanisms to control cold water pollution to downstream fisheries (Sherman et al., 2000), iron and manganese dissolution (Raman \& Arbuckle, 1989; Ismail et al., 2002), hydrogen sulphide release (Cowell et al., 1987) and oxygenation of the hypolimnion to expand fish habitats. Checklist 8.4 suggests questions to clarify before deciding on introducing artificial destratification or selecting a specific scheme.

\section{CHECKLIST 8.4: ASSESSING THE PROSPECT OF SUCCESS OF ARTIFICIAL DESTRATIFICATION}

- How strongly is the waterbody stratified, and during which months of the year?

- Are the dominant cyanobacterial taxa potentially scum-forming?

- Can mixing be designed to entrain cyanobacteria into deep, dark layers for long enough to substantially reduce their growth rate and to counteract their buoyancy? 
- Is the mixing design proposed technically adequate to meet the target?

- Is mixing (of shallower, weakly stratified waterbodies) likely to induce a shift to non-scum-forming filamentous cyanobacteria (e.g., Planktothrix agardhii) or (for mesotrophic stably stratified waterbodies) a shift to Planktothrix rubescens or Raphidiopsis raciborskii?

- Is there a risk that artificial mixing will substantially increase temperatures at the sediment surface, thus enhancing phosphorus release from the biodegradation of organic matter?

- For which part of the year must aerators be operated to effectively suppress cyanobacterial dominance?

- Is the required infrastructure and funding (reliable power supply, maintenance, monitoring) available for continuous operation?

\section{Operational monitoring for artificial destratification}

Options for parameters that indicate failure of devices installed for destratification are straightforward, including the electrical power consumption of devices installed for this purpose. For aerator designs causing a bubble plume, daily visual checks of the size of bubble plumes seen at the surface are a further option for operational monitoring.

\section{Validation of artificial destratification designs}

Whether or not the destratification system that is installed actually achieves the mixing target can readily be validated by measurements of temperature at different depths and locations, and in different weather situations or even seasons (in reservoirs, e.g., the simplest option can be at the surface and in the bottom outlet). One option is to collect data continuously or at short intervals using thermistor chains that relay these data back to the operator (these can also be used as online monitoring systems for operational monitoring of aerator function). Alternatively, temperature depth profiles can be monitored at specific occasions, focusing on weather conditions when thermal stratification has the best chances to develop in spite of the mixing, for example, during extended periods of sunny, warm and nonwindy weather. Such monitoring would demonstrate that the destratification scheme is sufficient to ensure mixing and is therefore fit for purpose.

If the outcome shows that further fine-tuning is necessary, improving the design may require more information on the response of the waterbody's thermal stratification as well as the phytoplankton populations. Data on wind, solar irradiation, temperature and precipitation from meteorological 
stations near to the waterbody are valuable for hydrodynamic modelling. Together with phytoplankton cell counts and nutrient data, information on reservoir or lake hydrodynamics is very useful in determining and confirming the conditions that promoted cyanobacterial growth. This serves to validate the mixing concept and enables predictive capacity for forecasting future cyanobacterial growth - and for risk assessment.

Such in-depth validation typically requires experts in limnology with a focus on phytoplankton ecology.

\subsubsection{Managing river flow regimes to suppress cyanobacterial growth}

Planktonic cyanobacteria generally do not develop blooms in rapidly flowing rivers. Possible reason for this may be increased turbidity due to high loads of inorganic particles and hence limited light availability, losses due to benthic grazing or highly fluctuating conditions lowering growth rates (Dokulil, 1994; Reynolds et al., 1994; Welker \& Walz, 1998; Caraco et al., 2006) - or combinations of these and other factors that prevent cyanobacterial (and other phytoplankton) blooms from developing within the limited time water flows towards the sea, in most cases within days or weeks.

In rivers with long stretches of slow flow, like the lowland MurrayDarling River in Australia, this is different: hydrophysical conditions remain fairly constant over long stretches of such rivers. If nutrient concentrations are also high, the cyanobacteria which are typically found in well-mixed shallow waterbodies - for example, Planktothrix agardhii and other fine filamentous species - may become dominant and reach high population densities. To break their dominance, hydrophysical interventions would need to introduce pronounced changes to flow or mixing conditions at time intervals in the range of 1-2 doubling times of the cyanobacteria, that is, within several days or one to two weeks.

Impoundments or constructed barriers markedly reduce both turbulent kinetic energy and river flow and increase residence times. For example, where, without impoundment, the water would take one week to travel from the foothills to the river's mouth (i.e., 1-2 doubling times of the cyanobacteria) impoundments can reduce this travelling time to many weeks. This gives cyanobacterial populations sufficient time for many cell divisions and thus for the formation of blooms. Where impoundments are being planned, this potential impact on water quality should be assessed. Where impoundments already exist and have been identified as one cause of cyanobacterial proliferation, managing them differently or even restoring natural flow regimes may be an option, depending on other management targets.

Low flow conditions in lowland rivers can even lead to stratification. The correlation observed between buoyant species of Dolichospermum and low flow in some large rivers suggests that the manipulation of flow 
may be used to control cyanobacteria (Baker et al., 2000; Maier et al., 2004). In regulated rivers, the magnitude and timing of discharge can be manipulated to disrupt stratification every few days, thereby controlling cyanobacterial growth. Bormans and Webster (1997) developed a mixing criterion for turbid rivers that can be used to determine the flow required to disrupt stratification.

River management strategies to generate higher flow and reduce the risk of cyanobacterial blooms depend upon the availability, cost and ability to deliver enough water to provide that flow. It is also important to weigh the likelihood of success and cost-benefit of such interventions against further socioeconomic criteria (i.e., the need for an impoundment to store water or enable shipping; loss of provision of water for irrigation) and ecological criteria (i.e., the implications of flow regime changes on the riverine ecosystem that is adapted to the slow flow or impoundment regime).

Checklist 8.5 suggests questions to address when considering changes in river flow management with respect to their impact on cyanobacterial growth.

\section{CHECKLIST 8.5: ASSESSING RIVER FLOW REGIMES AND OPTIONS FOR THEIR MANAGEMENT}

- Are data on flow rates available? If not, can they be collected?

- What is the goal for the flow management or manipulation regime: to reduce residence time and dilute cyanobacteria? To disrupt stratification and reduce growth through altering mixing and light availability?

- What changes in flow regime are required to reach this goal?

- Is enough water available stored upstream in the catchment for the flow rate targeted?

- Which other sectors need to be involved in developing a flow management strategy?

\section{Operational monitoring for flow regime management}

Operational monitoring will record whether river flows are as planned, that is, through measuring flow rates. For major rivers, data on river flow are often available from water resource authorities who generate them for other purposes.

\section{Validation of flow regime management}

Validation of the flow regime management involves monitoring whether the intended flow rates are achieved (for measuring them, see section 7.2). 


\subsubsection{Managing water retention time in lakes and reservoirs to suppress cyanobacterial growth}

Management interventions reducing water retention times in a waterbody may successfully reduce cyanobacterial biomass, if dilution rates can be achieved that are higher than their growth rates - that is, retention times of one a month or less. Retention time is the quotient of the basin volume divided by the inflow. For many waterbodies, particularly lakes, retention times are not well known, and they may be difficult to measure directly particularly if there is more than one inflow or if a lake is strongly connected to groundwater flows (see Chapter 7). Water budgets may be calculated from concentration changes of a conservative tracer substance like chloride analysed in the inflow(s), in the lake and in the outflow. As for managing river flow, a caveat may be the lack of water availability to increase the water exchange rate, particularly during seasons with little precipitation in the catchment.

\section{CHECKLIST 8.6: ASSESSING WATER RETENTION TIMES AND OPTIONS FOR THEIR MANAGEMENT}

- Are data on water retention times available? If not, can inflow and outflow rates be established or inferred from concentration differences of a tracer substance (like chloride)?

- Can a water retention time target of approximately one month or less be achieved in the lake or reservoir during the growing season?

- Are sufficient water volumes of suitable quality available in the catchment for this target?

- Are there conflicting interests for the use of this additional water or for environmental targets affected by diverting water to increase exchange rates?

\section{Operational monitoring of water retention time management}

Operational monitoring will serve to ensure that inflows to the waterbody remain in the predefined range, and thus, it will require monitoring inflow or outflow to determine whether the intended retention time is actually achieved. For reservoirs, data on outflow from the dam are usually available, and data on drinking-water abstraction may need to be included in the budget, if this volume amounts to more than a few percent of the river flow. 


\section{Validation of water retention time management}

Validation of the water retention time will focus on checking whether it is indeed short enough in all parts of the waterbody to achieve its target of reducing cyanobacterial biomass. Particularly for waterbodies with many bays, as is typical for reservoirs, retention time may not be homogenous and inflows may find a preferential flow path through them, with much lower water exchange rates in the bays. Monitoring cyanobacterial occurrence also at such locations is particularly important so that further measures can be taken if the management of retention time proves insufficient.

\subsection{ASSESSING AND CONTROLLING INTERNAL PHOSPHORUS RELEASE FROM THE SEDIMENTS}

The amounts of phosphorus $(\mathrm{P})$ released from sediments vary from negligible to being a substantial load for many years after external inputs have been reduced (Orihel et al., 2017). However, once a waterbody has reached a new equilibrium, the sediments may well become a sink rather than a source for phosphorus. Whether and when sediments are a source or a sink for phosphorus is governed by a range of conditions, in particular by

- water exchange rates across the sediment water interface;

- chemical and physical processes of precipitation and resolution as well as adsorption and desorption, which depend on the availability of binding partners for phosphorus in the sediment (e.g., silt from river inflow);

- biotic processes, that is, mineralisation of organic matter as well as bioturbation through fish and invertebrates which resuspend sediment;

- redox conditions and $\mathrm{pH}$ influencing the binding potential for phosphorus;

- temperature, with higher temperatures enhancing release through biodegradation of organic matter.

Chemical conditions in the upper sediment layers, temperature and waterbody mixing affect these processes. Iron-bound phosphorus is highly sensitive to oxygen concentrations and redox conditions: when such sediment surfaces become anoxic during summer stratification, phosphorus concentrations in the water above the sediment may increase significantly, and if some of this water is mixed into upper layers during the optimum growing season of cyanobacteria, it may provide nutrients for their further growth. In some situations, this may act as feedback loop, with more cyanobacterial growth increasing $\mathrm{pH}$ and the amount of organic material which consumes oxygen when it degrades, thus triggering more phosphorus release. 
Such processes can have a significant impact on the seasonal or interannual changes of phosphorus concentrations (Xie \& Xie, 2002).

Aerobic phosphorus-release mechanisms may also be significant, that is, through microbial degradation of organic material, enhanced through bioturbation by feeding fish and invertebrates (Gardner et al., 1981; Søndergaard et al., 2003; Hölker et al., 2015).

Phosphorus budgets can be estimated by balancing phosphorus loads to the waterbody against losses from the waterbody. This requires data on water inflow and outflow (preferably from continuous recording) and on phosphorus concentrations in this water (at least from monthly sampling, ideally supplemented by flow-based monitoring and sampling to capture events likely to change the load, i.e., pronounced changes in flow). Determining P concentrations requires capacity for sampling and laboratory analysis. Determining all relevant inflows and outflows can be challenging, particularly where there are many small and variable streams and/or influence from groundwater (see section 7.2). For thermally stratified lakes and reservoirs, it is relevant to measure depth profiles of $\mathrm{P}$ and temperature in order to differentiate between the $\mathrm{P}$ content of the epilimnion and the hypolimnion and to assess the stability of stratification: this allows an understanding of the potential for P-rich water from deep layers to reach the surface layer. One possible outcome of a P budget may be that sediments act as a sink for $\mathrm{P}$ on an annual basis and nonetheless as a $\mathrm{P}$ source during part of the summer, thus making $\mathrm{P}$ available for phytoplankton growth.

While such P budgets help clarify the role of $\mathrm{P}$ from the sediments for the overall $\mathrm{P}$ concentration in the waterbody, they scarcely contribute information for differentiating between the two most important processes of $\mathrm{P}$ release: desorption of iron-bound $\mathrm{P}$ and mineralisation of organically bound $P$. If measures are to be taken to reduce $P$ release from the sediment, this differentiation is important for choosing an effective method. The potential for the release of redox-sensitively iron-bound $\mathrm{P}$ and organic-bound $\mathrm{P}$ may be estimated from chemical analyses of sediment cores following Psenner et al. (1984), and this requires access to expertise and capacity in sediment chemistry. Further indication may be derived from the analysis of time patterns of phosphorus peaks in the water above the sediment in relation to temperature (which strongly governs mineralisation) and redox conditions (indicated, e.g., by the concentrations of oxygen or nitrate, or measured directly with a probe; an example is given by Chorus \& Schauser, 2011). Although such analyses require time and expertise, measures to reduce internal phosphorus loads require investment, and this information is important to estimate their chance of success and thus avoid failed investment.

If a thorough analysis reveals $\mathrm{P}$ release from the sediment to be a major source of $\mathrm{P}$ in the waterbody, and if demands for water use do not allow waiting for years until measures to control the external load have taken effect and sediments turn into a sink rather than a source for P, it may 
be necessary to reduce the in-lake phosphorus pool. This can particularly be the case if water exchange rates are low. Sometimes this situation also applies to lakes that are naturally eutrophic, like lakes in western Canada situated on phosphorus-rich glacial till (Prepas et al., 1997). A comprehensive review by Bormans et al. (2016) of opportunities and methods for controlling internal phosphorus loading gives many examples and case studies of techniques and an analysis of their success. These examples include dredging (see section 8.6.2), hypolimnetic aeration or oxygenation (see section 8.6.3) and hypolimnetic withdrawal (see section 8.6.4).

Checklist 8.7 serves for a first assessment of whether or not internal phosphorus control measures should be considered.

\section{CHECKLIST 8.7: ASSESSING POTENTIAL BENEFITS AND THE PROSPECT OF SUCCESS OF INTERNAL PHOSPHORUS CONTROL MEASURES}

- Have external inputs been sufficiently reduced so that these loads do not override the effect of the internal measure?

- Has a comprehensive phosphorus budget been calculated and an analysis of phosphorus release from the sediments been conducted, as outlined above, to clarify the relevance of the sediments as phosphorus source to the waterbody?

- Is the control of internal phosphorus loading necessary because external measures are not likely to reduce phosphorus concentrations in the waterbody sufficiently within the targeted time frame?

Several options for internal phosphorus control are introduced in the following sections. Their best choice depends on hydrological conditions and in particular on sediment chemistry. Investing in sediment analysis to determine phosphorus-binding forms and binding partners before investing in sediment treatment is strongly recommended.

\subsection{I $P$ reduction by in-lake phosphorus precipitation and capping}

The phosphorus-binding capacity of sediments depends upon the sediment type, primarily on the sediment's adsorption capacity. If the sediment has received phosphorus-rich waters for a considerable period of time, then the adsorption capacity may be saturated. Adsorbents naturally reach waterbodies with the load of silt, mineral and clay particles eroding from the catchment. If measures to reduce phosphorus loading in the catchment shift the balance between P and adsorbents reaching the waterbody, the new 
sediment forming in the waterbody may attain a sufficient binding capacity without further measures. Adding P-adsorbing substances (flocculants) to the waterbody can accelerate this process.

Conversely, waterbodies with naturally high concentrations of iron or calcium compounds in the inflow and thus sufficient adsorption capacity to induce natural phosphorus precipitation may lose this ability through measures in the catchment area or changes in inflow regime.

Precipitation of phosphorus from the waterbody to the sediment, and sediment "capping", can be successful if phosphorus then remains permanently bound in the sediment. This is either done by binding $\mathrm{P}$ to insoluble iron compounds (which, however, remain insoluble only under oxidative conditions), aluminium sulphate (alum) or by adsorption onto calcium carbonate or clay particles modified to enhance adsorption. Experience with both failures and successes has shown that effective treatment requires a careful design on the basis of comprehensive understanding of the sediment chemistry and hydrology of the individual waterbody (Cooke et al., 2005).

Prerequisites for lasting success include low external P loading; a sufficient oxygen supply of the deep water if capping is done with redox-sensitive compounds; sufficient depth to prevent sediment resuspension; and appropriate choice of $\mathrm{P}$-adsorptive materials used as flocculants such as ferric salts (chlorides, sulphates), ferric aluminium sulphate, zeolites, lanthanum-modified clay, clay particles and lime $\left(\right.$ as $\mathrm{Ca}(\mathrm{OH})_{2}$ and as $\left.\mathrm{CaCO}_{3}\right)$; and by-products of mining, mineral processing or industries (Akhurst et al., 2004; Douglas et al., 2016). Douglas et al. (2016) describe the mode of action of $\mathrm{P}$ adsorbents and report that those with substantial uptake capacity are generally enriched in $\mathrm{Ca}, \mathrm{Fe}$ and/or $\mathrm{Al}$; they may also incorporate the rare earth element lanthanum (La). These compounds may all have some degree of undesirable side-effects, from toxicity to disrupting food resource supply to zooplankton; therefore, care needs to be taken with their application.

Ferric salts are effective in precipitating phosphorus, but difficult to handle because of their aggressive acidity. In particular, the iron-phosphorus complex is stable only under oxic conditions. Therefore, the application of ferric salts usually requires oxic conditions to be ensured down to the sediment, for example, through continuous aeration (which may remain necessary for many years, until $\mathrm{P}$ concentrations and plankton biomass are so low that the waterbody remains oxic down to the sediments including during summer). In practice, oxic conditions are unlikely to be reached quickly in waterbodies that have experienced years or decades of hypertrophic conditions accumulating a thick anoxic sediment rich in $\mathrm{P}$ and biodegradable organic matter. This will continue to degrade, consuming oxygen and thus reducing the iron-phosphorus complex, releasing the bound phosphorus.

In addition, Prepas et al. (1997) pointed out that iron may be a limiting micronutrient in some systems, and in such situations, treatment with 
ferric salts may actually stimulate growth of cyanobacteria and algae. This stimulation cannot occur if sufficiently stringent phosphorus limitation can be achieved.

Aluminium sulphate treatment does not require oxic conditions as it is poorly soluble, provided $\mathrm{pH}$ conditions remain neutral or high $\mathrm{pH}$. However, it may decrease $\mathrm{pH}$ in waters with low buffering capacity, and this leads to solubilisation and problems of alum toxicity.

Although lime (both $\mathrm{Ca}(\mathrm{OH})_{2}$ and $\mathrm{CaCO}_{3}$ ) has been used primarily to coagulate and precipitate phytoplankton cells (see also section 8.4.9), it has also been successfully applied to precipitate phosphorus from the water, for example, in farm dugouts (dams) in Alberta, Canada (Murphy \& Prepas, 1990; Zhang \& Prepas, 1996) and in other natural waters and wastewaters (Douglas et al., 2016). Hart et al. (2003) assessed the effectiveness of three forms of $\mathrm{CaCO}_{3}$ (crushed limestone and two forms of precipitate calcite) on phosphorus binding in lake sediments. Limestone was found to be ineffective, but the precipitated calcite products reduced phosphorus release by up to 100 times under anoxic conditions. It appears that $\mathrm{Ca}(\mathrm{OH})_{2}$ is more effective than $\mathrm{CaCO}_{3}$ in precipitating phosphorus (Murphy \& Prepas, 1990), and it is possible that the technique may be more effective in these conditions than in soft water.

Another approach is to bind $\mathrm{P}$ in sediments with lanthanum-modified clay (Douglas et al., 2016). Robb et al. (2003) reported that modified clay successfully bound phosphorus in the rivers of Canning and Vasse in Australia. Akhurst et al. (2004) investigated the ability of modified clay to reduce the levels of phosphorus released from the sediments of Lake Ainsworth, Australia. They found the bentonite clay highly effective at reducing $\mathrm{P}$ under both anoxic and oxic conditions. However, levels of dissolved Fe were enhanced with its use, and this may result in a water quality issue (see above). Ross and Cloete (2006) showed a significant reduction in filterable reactive phosphorus (FRP) and a drop in the amounts of phytoplankton after the addition of modified clay to Hartbeespoort Dam, South Africa.

A natural phenomenon potentially useful in specific circumstances is the effect of desiccation/oxidation of sediments on $\mathrm{P}$ adsorption as this can significantly reduce the release of phosphorus from lake sediments upon rewetting attributable to a number of interrelated factors (Baldwin, 1996; Mitchell \& Baldwin, 1998; Baldwin et al., 2000). While it is not known how long the effects of desiccation will last, drying the lake sediments may be a suitable strategy to reduce $\mathrm{P}$ release in some shallow lakes or reservoirs, if, for example, natural seasonal wetting and drying cycles can be (re)introduced.

As already mentioned above, some precipitation and/or capping agents have an impact (adverse or toxic effect) upon lake biota. Douglas et al. (2016) describe the need to establish the ecotoxicological profile of P-adsorptive 
material applied to natural waters; these authors also provide references to available ecotoxicological test that can be employed for this purpose.

\section{CHECKLIST 8.8: ASSESSING THE PROSPECT OF SUCCESSOF P REDUCTION BY IN-LAKE PHOSPHORUS PRECIPITATION OR SEDIMENT CAPPING}

- Has the P-binding capacity of the sediments been assessed?

- How large is the "inventory" of phosphorus likely to be released from the sediments?

- Have the phosphorus loads (inputs) been assessed?

- Has the oxygen consumption of the sediment during thermal stratification been assessed?

-What substances are to be precipitated for sediment capping?

- Do the compounds have appropriate local regulatory approval for application to waterbodies?

- Do they have side-effects? If so, what are they and to which extent?

- Do further stakeholders need to be involved to decide on their acceptability?

\section{Operational Monitoring for in-Lake Phosphorus Precipitation and Capping}

For these techniques, it is important to monitor the application with respect to sufficient amounts and even distribution of the substance applied throughout the waterbody during application. After the measure, inspecting the sediment surface from time to time may be important to ensure that the capping cover is still sufficiently thick.

\section{Validation of in-Lake Phosphorus Precipitation and Capping}

As for $\mathrm{P}$ removal by flushing, validation of precipitation and capping measures requires a monitoring programme of the $\mathrm{P}$ content of the waterbody, that is, concentrations in different depths. For lakes and reservoirs with a very heterogeneous shape, possibly this needs to include bays and subsystems. P concentration monitoring may need to be repeated at intervals (e.g., annually or in each season) to ensure that the measure was sufficient and further interventions are not necessary. If concentrations decline to the level targeted, this is sufficient, and the P-response monitoring programme can be reduced to periodic reviews (e.g., once per year in spring). If not, this indicates either insufficient capping or external phosphorus sources that require reduction before capping can be successful. 


\subsection{2 $P$ reduction by sediment dredging}

Dredging to remove P-saturated sediments intuitively appears to be an attractive solution. However, it is costly and will reduce release rates only if

1. (as for all internal measures to reduce $\mathrm{P}$ release), the internal phosphorus load from the sediment is significant in relation to the external load;

2 . it is carried out all the way down to sediment layers with a lower or less mobile phosphorus content;

3. phosphorus-rich interstitial water from the sediments dredged is handled in such a fashion that it does not reach the waterbody and cause additional inputs during the dredging operation;

4. dredged sludge can be deposited where it does not create a new external load through runoff into the waterbody.

In some urban and industrial regions, dredging is not possible or complicated by high concentrations of heavy metals and organic contaminants in the sediments which would then require disposal as hazardous waste. Dredging may be a good solution for smaller waterbodies, the trophic state of which can additionally be improved by increasing their depths, or which also need to be cleared of dumped rubbish. A review of dredging case studies by Bormans et al. (2016) found both successful and unsuccessful examples and that dredging is costly. The authors concluded that where it has been unsuccessful, in most cases the reason for this was that external loading was not sufficiently controlled, and that it is more successful when combined with other restoration techniques.

\section{CHECKLIST 8.9: ASSESSING THE PROSPECT OF SUCCESS OF P REDUCTION BY DREDGING}

- Is the input of phosphorus from the catchment area low enough to ensure that sediment removal will have a lasting effect?

- Will dredging remove P-saturated sediments down to layers that are not likely to cause a continuing internal P load?

- Is a suitable site available for depositing the sludge, so that P-rich sludge water can be kept away from the waterbody?

\section{Operational monitoring for removal of in-lake phosphorus by dredging}

Operational monitoring of dredging involves checking, for example, by visual monitoring of the amounts dredged and the sites at which dredging is performed, that the amount of sediment intended for dredging is 
actually removed from the sediment surface areas at the depths designated for removal. Visual inspection can serve to monitor that dredged sludge is not deposited so close to the waterbody that will reintroduce part of the phosphorus load through seepage, erosion and stormwater runoff.

\section{Validation of removal of in-lake phosphorus by dredging}

Dredging may easily miss the target of removing all of the sediment layers which release phosphorus, and as for other P removal methods, validation requires monitoring whether the $\mathrm{P}$ content of the waterbody responds sufficiently to the measure, that is, whether concentrations decrease to the target level. If concentrations decline to the target level, this is sufficient, and the P-response monitoring programme can be reduced to periodic reviews (e.g., once each year in spring). If not, this indicates either insufficient dredging or external phosphorus loads that require reduction before dredging can be successful.

\subsubsection{Binding phosphorus through hypolimnetic aeration}

Hypolimnetic aeration or oxygenation (with pure oxygen) aims at providing oxygen to the hypolimnion without disrupting thermal stratification to enhance the binding of phosphorus to iron (Bormans et al., 2016). The prerequisite for this technique is that the waterbody is thermally stratified during relevant parts of the year and that the sediment contains enough redox-sensitive P-binding material, that is, iron. If the ratio between iron and phosphorus is low, oxidising the sediment will not help. Schauser et al. (2006) and Schauser and Chorus (2007) highlight this with a case study of Lake Tegel, Germany: budget calculations demonstrated that P accumulating in the hypolimnion did not primarily result from anoxic release of iron-bound $\mathrm{P}$, but largely originated from the mineralisation of recently sedimented biomass, and later investigations showed that indeed the sediment's iron concentrations were rather low in relation to P concentrations. In this case, the increase of sediment temperatures caused by poorly managed aeration actually enhanced this biodegradation-driven P release and scarcely served to bind $P$.

Other researchers discuss further examples of marginal or lack of success of hypolimnetic aeration where the chief target of aeration was reducing phosphorus release from sediments (Gächter \& Wehrli, 1998; Gächter \& Müller, 2003; Hupfer \& Lewandowski, 2008; Bormans et al., 2016). These examples show that planning hypolimnetic aeration requires a particularly good understanding of the sediment chemistry for success of this intervention, and it is therefore not recommended without this knowledge. 
While hypolimnetic aeration may use aerators like those used for artificial destratification (section 8.2.1), these aerators must be designed and operated in a way that minimises the disruption of thermal stratification for two reasons: (i) to avoid accelerating P release from the sediment by from biodegradation and (ii) because stable stratification resists deep mixing and entrainment of nutrients from the hypolimnion into epilimnion where they can be used for phytoplankton growth. Designs to avoid destratification have been used for fisheries management where warm surface waters and cool bottom water are both required for fish habitat (Moore et al., 2014), but it also has the advantage that nutrients can remain limiting in the surface water layers. The challenge is to inject oxygen into the hypolimnion in such a way that it does not form rising air bubbles that can form a plume and disrupt stratification.

Hypolimnetic oxygenation can be achieved with a number of methods, including airlift pumps, side-stream oxygenation and direct injection of air or oxygen using a bubble contact chamber like a Speece cone (Beutel \& Horne, 1999; Cooke et al., 2005; Singleton \& Little, 2006). These techniques vary in cost, but they are all relatively expensive. The technique is also used and well understood for controlling soluble iron and manganese release in drinking-water reservoirs (Gantzer et al., 2009).

Hypolimnetic aeration can easily be a waste of money if selecting this management option is not carefully designed and operated and not based on a good understanding of the waterbody's hydrodynamics, sediment oxygen demand, iron concentration and nutrient release rates as well as the relative contribution of internal versus external nutrient load (see Singleton \& Little, 2006).

\section{CHECKLIST 8.10: ASSESSING THE PROSPECT OF SUCCESS OF BINDING P THROUGH HYPOLIMNETIC AERATION}

- Does the sediment contain enough redox-sensitive binding sites (i.e., iron) for a success chance of this strategy?

- Is the system designed to keep destabilisation of thermal stratification minor?

- As aeration will continue to be necessary for a prolonged time period, is funding for maintenance and operation secure for several years to come?

\section{Operational monitoring for binding $\mathbf{P}$ through hypolimnetic aeration}

Operational monitoring of hypolimnetic aerators can be performed in a similar way to that for artificial mixing described above, that is, by recording electrical power consumption of the pumps, the oxygen concentration in the water or some other indicator for their continuous operation. 


\section{Validation of binding $P$ through hypolimnetic aeration}

As for artificial mixing, recording temperature and dissolved oxygen profiles over depth is also important for validation, in this case to demonstrate that the function of the aerators is actually limited to the hypolimnion, without significant impact on the layers above. This can either be done continuously using a thermistor chain, or at regular intervals (e.g., weekly), or under selected sensitive conditions where stratification is less stable than normal, for example, in spring when it begins developing, after storms or in late summer when it begins eroding. Validation should also check for (unintentional) entrainment of dissolved substances (particularly phosphorus) from the hypolimnion into the surface water, particularly if temperature profiles indicate that aeration does cause some intensification of water exchange between the hypolimnion and surface-near water layers.

In particular, the further primary parameter to monitor is the oxygen concentration in the hypolimnion in order to validate that the measure actually achieves the targeted oxygen concentration. This can be done periodically, for example, every two weeks during thermal stratification or continuously if sensors are installed. The second important level of validation is to show that this target oxygen concentration - if it is met - is actually successful in suppressing phosphorus release. As for the other internal measures for reducing $\mathrm{P}$ in a waterbody, this requires monitoring phosphorus concentrations. If concentrations decline to the target level, this is sufficient, and the P-response monitoring programme can be reduced to periodic reviews (e.g., once per year in spring)

Possibly, if target levels are not met, either the sediment is less of a P source than assumed (indicating the presence of further sources) or P release from the sediments is not as redox-sensitive as assumed and rather driven by mineralisation, which is more effective if oxygen is present and therefore may even be enhanced by aeration, particularly if this measure increases the water temperature at the sediment surface.

\subsubsection{Withdrawal of $P$ with the bottom water (hypolimnetic withdrawal)}

In thermally stratified eutrophic lakes, phosphorus accumulates in the hypolimnion during conditions of stable stratification during summer. While during summer this layer is largely separated from the epilimnion in which phytoplankton grows, autumn and winter mixing will redistribute this phosphorus throughout the waterbody, making it available for phytoplankton for spring growth. Although most natural outflows drain surface water, it may also be possible to abstract hypolimnetic water instead, by installing a pipe that reaches down into the hypolimnion and has an outlet positioned lower into the outlet (like an "upside-down U"; Olszewski, 1961). For reservoirs 
with multiple outlets, it is often possible to use a lower outlet of the dam to withdraw hypolimnetic water.

Where $\mathrm{P}$ concentrations in the hypolimnion are high and the hypolimnion depth and volume are considerable, this method can reduce inlake concentrations significantly. For example, in the Swiss Mauensee, the biomass of Planktothrix rubescens was reduced from 152 to $42 \mathrm{~g} \mathrm{~m}^{3}$ (corresponding to biovolume of 152 and $42 \mathrm{~mm}^{3} / \mathrm{L}$ ) using this approach (Gächter, 1976). With data from numerous case studies, Nürnberg (1997; 2007) compiled the advantages of hypolimnetic withdrawal during summer stratification as a method based on the selective outflow of P-rich water. Further case studies are given by Bormans et al. (2016). Advantages of the method are as follows:

- It addresses the cause of eutrophication.

- It does not introduce chemicals.

- It can be used without changing the water budget.

- It can break the cycle of enhanced sediment accumulation of total phosphorus (TP).

- If hydrological regimes allow, it can flush more phosphorus out of the system than the sediments accumulate and/or release each year.

- Costs are relatively low, and where operation is by gravity, it does not require energy.

Hypolimnetic withdrawal is effective only if enough water flows into the lake to balance consumptive needs, that is, amounts abstracted for use (e.g., drinking-water supply, irrigation). It is possible only if the depth and volume of the hypolimnion are sufficiently large to have an overall impact on the phosphorus budget of the waterbody without removing the entire hypolimnion: if drawdown is too pronounced, this may destabilise thermal stratification, causing entrainment of P-rich hypolimnion to surface layers and increasing temperatures at the sediment surface, which in turn enhances the release of $\mathrm{P}$ through mineralisation of organic matter.

In addition, impairment of water quality downstream may require attention if oxygen demand and phosphorus concentrations of the water removed are high in relation to the total flow of the receiving waterbody. Downstream phosphorus pollution may be avoided by treatment of the hypolimnion outlet with chemical phosphorus precipitation. In addition, the low temperatures of the hypolimnetic water may have an impact upon downstream biological processes, like fish breeding. Use of this phosphaterich water for agricultural purposes may be an option, depending upon local needs for irrigation in addition to considering the implications of other contaminants which can be dissolved in water with a low oxygen concentration (e.g., iron and manganese). 


\section{CHECKLIST 8.II: ASSESSING THE PROSPECT OF SUCCESS OF P REDUCTION THROUGH HYPOLIMNETIC WITHDRAWAL}

- Are the depth and volume of the hypolimnion sufficient to allow major removal without destabilising thermal stratification?

- Does enough water flow into the waterbody to balance the hypolimnion offtake, or is some drawdown of the water level acceptable?

- Have downstream effects been assessed and stakeholders possibly affected been involved?

\section{Operational monitoring for removing $\mathbf{P}$ through hypolimnetic withdrawal}

Operational monitoring of hypolimnetic withdrawal should include monitoring of both the reservoir water and the outlet (e.g., temperature or conductivity) to ensure the desired target layer is being removed.

\section{Validation of $\mathbf{P}$ removal through hypolimnetic withdrawal}

As for artificial mixing, measuring temperature profiles is also important for validation. This can either be done continuously using a thermistor chain, or at regular intervals (e.g., weekly) or under selected sensitive conditions where stratification is less stable than normal, for example, in spring when it begins developing, after storms or in late summer when it begins eroding.

In particular, the additional parameter to monitor is the oxygen concentration in the hypolimnion in order to validate that low oxygen or anoxic water is being removed as an additional surrogate for phosphorus content.

\subsubsection{Reducing the $P$ content of the waterbody by flushing}

Flushing with water of low phosphorus concentrations can substantially accelerate recovery from internal loading by removing in-lake phosphorus that would otherwise be recycled for several seasons. If suitable water is available in sufficient quantity, flushing can be a very effective tool for reduction of cyanobacterial proliferation. Successful examples include Veluwemeer in the Netherlands (Reeders et al., 1998), Moses Lake in the USA (Welch et al., 1972) and two lakes in Germany (Figure 8.1). The latter show that if $\mathrm{P}$ concentrations in the inflow are sufficiently low (in these 
cases $<10-20 \mu \mathrm{g} / \mathrm{L} \mathrm{TP}$ ), exchanging the lake's water volume $2-4$ times per year can reduce TP concentrations from several hundred $\mu \mathrm{g} / \mathrm{L}$ to $20-50 \mu \mathrm{g} / \mathrm{L}$ within less than 10 years despite a continued internal load from the sediments and some remaining external load. These examples show that while diluting cyanobacteria out of a waterbody as discussed in section 8.5.3 requires extremely high flushing rates - that is, in the range of an exchange of the water volume once a month - diluting out phosphorus can be successfully done more slowly. The time it takes to achieve the target phosphorus concentration depends chiefly upon the initial P content (i.e., the waterbody's volume multiplied with its mean concentration of total $\mathrm{P}$ ) and the $\mathrm{P}$ load of the inflow(s) (i.e., concentration multiplied with the water volume entering the waterbody) plus the internal P load (i.e., the amount released from the sediments, which can be estimated by budget calculations as outlined above and described in Schauser and Chorus (2009)).

A flushing option for reservoirs is to use heavy rainfall events to fill the reservoir with water of lower $\mathrm{P}$ concentration while releasing water with higher concentration downstream. For thermally stratified waterbodies,
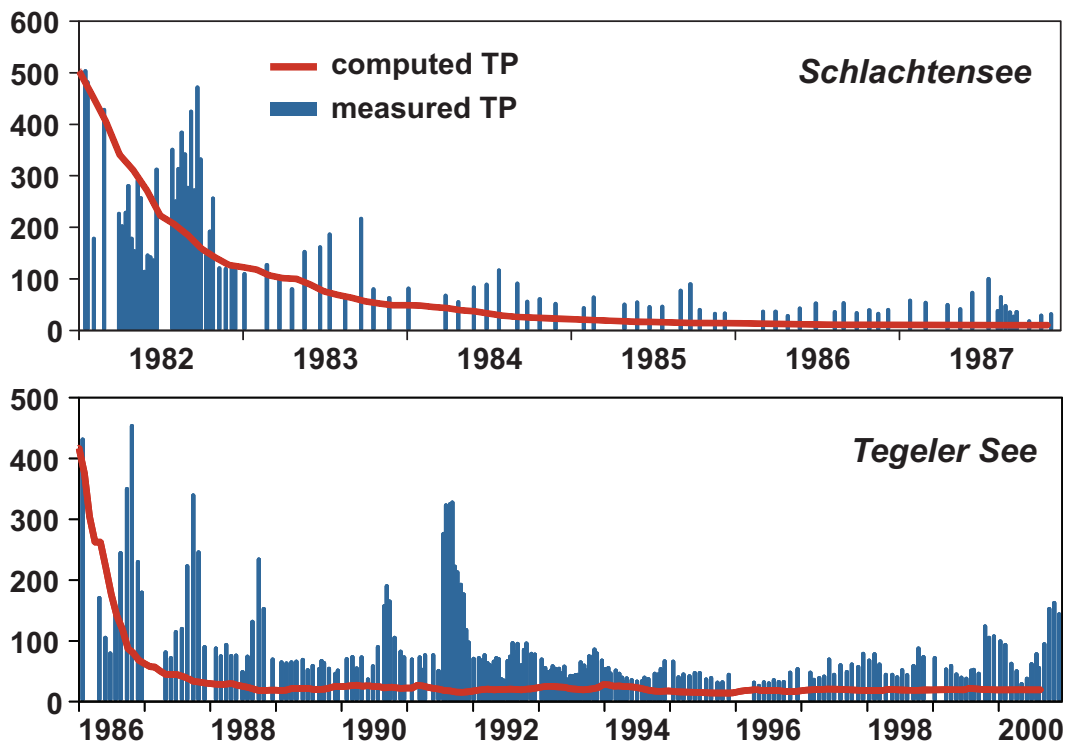

Figure 8.I Theoretical dilution of concentration of total phosphorus (TP) in two Berlin lakes after flushing with water of low TP concentrations began (curves) compared to concentrations actually measured (bars): for Schlachtensee (a; flushing rate of 2 times per year with water containing $\sim \mu \mathrm{g} / \mathrm{L} \mathrm{TP}$ ), the impact of other TP sources was much lower than in Tegel (see b; flushing rate of 2-3 times per year with water containing $\sim 20 \mu \mathrm{g} / \mathrm{L}$ TP) where the marked seasonal peaks of the concentrations measured in the lake indicate substantial further TP sources. (Data from Chorus \& Schauser, 2011.) 
this can be particularly effective if water can be released from P-rich bottom layers, as described above. However, this measure causes a relocation of the phosphorus to a downstream waterbody, and this requires impact assessment with the stakeholders responsible for that waterbody. If the amount released and its $\mathrm{P}$ load is small in relation to the river flow into which it is released, this may not cause a substantial change of $P$ concentrations in that river.

\section{CHECKLIST 8.12: ASSESSING THE PROSPECT OF SUCCESS OF P REDUCTION BY FLUSHING}

- Has a P budget been established, and have water volumes needed for flushing been estimated? Which $\mathrm{P}$ concentration can be achieved by flushing?

- Is sufficient water of suitable quality available in the catchment with significantly lower $\mathrm{P}$ concentration to achieve targets for the waterbody by flushing?

- What are the oxygen and phosphorus concentrations in the water to be released, and what potential impact will that have downstream of the release?

\section{Operational monitoring for $\mathbf{P}$ reduction by flushing}

Similar to operational monitoring for managing river flow or water retention times, operational monitoring for $\mathrm{P}$ reduction by flushing should also record whether flows are occurring as planned, that is, through measuring flow rates or other indicators of water exchange rates, for example, concentrations of tracers such as chloride. Where a specific selected water layer is to be drained from a thermally stratified waterbody, it is advisable to monitor the water temperature both in the waterbody and in the released flow to ensure that the layer actually being drained is indeed the one targeted.

\section{Validation of $P$ reduction by flushing}

Validation of the flow regime management to flush $\mathrm{P}$ out of the systems requires monitoring the $\mathrm{P}$ content of the waterbody, that is, concentrations in different depths and for lakes and reservoirs with very heterogeneous shape, possibly also in different bays and subsystems. If concentrations decline to the target level, this is sufficient, and the P-response monitoring programme can be reduced to periodic reviews (e.g., once a year in spring). If not, more detailed sampling and analyses of $\mathrm{P}$ concentrations 
in tributaries and at the outflow may be needed in order to improve the $\mathrm{P}$ budget calculation as a basis for identifying the remaining P sources (e.g., surface runoff, minor tributaries or sediment release).

\subsection{BIOLOGICAL CONTROL OF CYANOBACTERIA}

The term "biomanipulation" describes a range of techniques that influence phytoplankton community composition and growth by influencing parts of the food web of a lake. One approach aims to stimulate the growth of zooplankton that graze phytoplankton and is termed the "top-down" approach for phytoplankton control, as opposed to "bottom-up control" by nutrient reduction. The other approach aims at stimulating the growth of submerged aquatic plants ("macrophytes") or reeds that can serve two functions: they compete with phytoplankton for nutrients, and they provide refuges for zooplankton (thus supporting the top-down approach). Both approaches do not specifically address cyanobacteria, but phytoplankton in general. If these measures successfully decreased phytoplankton biomass and thus turbidity, this tends to favour species other than cyanobacteria, thus shifting species dominance away from cyanobacteria.

Biomanipulation as a management tool to reduce algal or cyanobacterial growth is most likely to be successful in situations of moderate nutrient concentrations (i.e., total phosphorus (TP) $<50 \mu \mathrm{g} / \mathrm{L}$ ) and in many situations also requires the reduction of nutrient loads. Experience shows that as long nutrient concentrations remain high, the risk that the ecosystem switches back into its original state is also higher. Also, stimulating zooplankton grazing without reducing concentrations of nutrients may stimulate dominance of grazing-resistant phytoplankton species, such as colony-forming (Microcystis, Aphanizomenon) or filamentous cyanobacteria (Planktothrix agardhii) (see section 4.1.5). For scientific reviews on biomanipulation, see Triest et al. (2016), DeMelo et al. (1992), Kitchell (1992), Carpenter \& Kitchell (1996), Moss et al. (1994) and Jeppesen et al. (2007a).

A striking example of how biomanipulation can complement and enhance nutrient control measures to return lakes back to a clear state is documented by Ibelings et al. (2007) for the shallow lake Veluwemeer in the Netherlands: as nutrient concentrations in the lake increased in the 1960s, biota shifted from a macrophyte-dominated state to a turbid phytoplanktondominated state. Even though nutrient inputs and in-lake concentrations were significantly reduced and overall phytoplankton biomass declined, this state was resistant to change and macrophytes did not reappear; that is, the lake remained in a stable turbid state (Scheffer \& Carpenter, 2003). This state was maintained by resuspension of sediments both through wind and through benthivorous fish. A significant reduction in the bream population allowed zebra mussels to recolonise and clear the water with their high filtration capacity. The clearing of the water then enabled macrophytes to 
recolonise, and these macrophytes in turn support and contribute to keeping the water clear by binding nutrients in their biomass.

These examples demonstrate the complexity of aquatic ecosystems and highlight the potential for different management options that may need to be tested in practice to find the approach which is most effective in the specific waterbody. Regardless of whether biological controls are being considered via fish stock management or through the introduction of macrophytes - or both - the following checklist helps assess the success chances of a biological approach.

\section{CHECKLIST 8.13: ASSESSING THE PROSPECT OF SUCCESS OF BIOLOGICAL CONTROL MEASURES}

- Is the waterbody only slightly eutrophic, thus rendering the food web susceptible to a "switch" in species composition away from cyanobacterial dominance, or are total phosphorus concentrations high (>50 $\mathrm{g} / \mathrm{L})$, with stable dominance of filamentous or colony-forming cyanobacteria, which are poorly edible by zooplankton and likely to cause too much turbidity for macrophyte growth?

- Has the ecosystem of the waterbody been intensively studied for at least I-2years, thus providing an in-depth understanding of trophic interactions as a basis for planning biomanipulation measures?

- Is funding available to continue these studies in order to monitor the ecosystem response, to possibly fine-tune the management of the measures taken and/or to repeat them if necessary?

The following two sections provide an introduction into the two biological approaches - that is, supporting zooplankton grazing by managing fish which would otherwise decimate the zooplankton and supporting recolonisation of shallow areas of a waterbody with macrophytes.

\subsection{Suppressing cyanobacteria through increasing grazing pressure by fish stock management}

Interventions into established hypertrophic ecosystem structures by fish stock management techniques have been successful, particularly in small ponds and lakes over shorter periods of time (Hrbáček et al., 1978). The target to increase zooplankton grazing pressure on phytoplankton can be achieved by reducing the populations of fish that feed on zooplankton either by regularly removing such planktivorous fish manually, that is through net hauls, or by introducing predatory fish that feed on the planktivorous fish. Numerous examples and potential challenges of this strategy 
are discussed extensively by Triest et al. (2016). These authors include examples of insufficient removal or suppression of planktivorous fish, insufficient macrophyte coverage to provide refuges for zooplankton as well as for the fry of predatory fish (which are intended to reduce the planktivorous fish) as well as unintentional promotion of the dominance of poorly edible cyanobacterial species. These potential pitfalls highlight the need for comprehensive previous studies of ecosystem as well as for ongoing monitoring after measures have been undertaken (see also Reynolds, 1997).

A successful contrasting example from a hypereutrophic subtropical lake in China suggests that cyanobacteria could be controlled directly by fish grazing upon them (Xie \& Liu, 2001). This is a different approach from traditional biomanipulation through enhancing zooplanktonic grazers, and it is reported to have been effective for over 30 years.

The monitoring of fish populations is time-intensive and requires substantial expertise, and consequently, this is often a major cost factor for such biomanipulation schemes, while the fish stock itself may be comparatively cheap. Biomanipulation requires continued monitoring of the development of the plankton as well as regular stocking with predatory fish. Where fishing or angling occur to the extent that it impacts the fish population, it is important to involve anglers and fishermen in planning and operating the measure. They need to be encouraged not to decimate the predatory fish but to remove planktivorous fish (which tend to be unattractive commercially or as trophy), as removing these may support the desired outcome. Biomanipulation through fish stock management may not continue to work naturally and unaided unless nutrient concentrations are also sufficiently reduced.

\section{CHECKLIST 8.14: ASSESSING THE PROSPECT OF SUCCESS OF BIOLOGICAL CONTROL OF CYANOBACTERIA THROUGH INCREASING GRAZING PRESSURE BY FISH STOCK MANAGEMENT}

- Is the biotic structure of the waterbody ecosystem described and understood - that is, are data available on fish stock, zooplankton population sizes and biomass of phytoplankton taxa?

- Do these results suggest that biological control will be successful?

- Does the trophic state also imply that success of biological control of cyanobacteria can be successful?

- Can stocking measures of predatory fish or removal of planktivorous fish be repeated, for example, annually?

- Can anglers be prevented from removing the predatory fish introduced for biomanipulation? 


\section{Operational monitoring of grazing pressure management by fish stock management}

Fish stock management interventions tend to be discontinuous, and accordingly so is operational monitoring. It addresses whether planktivorous fish have been removed as intended and/or predatory fish fry have been stocked as intended. This can be through, for example, surveillance of the documentation of the hatcheries and operators involved in stocking operations as well as through monitoring compliance of angling activities to permits.

\section{Validation of grazing pressure management by fish stock management}

It is challenging to validate fish stock management as to whether or not it is effectively changing the food web of a waterbody. This validation requires monitoring the population changes of fish, zooplankton and phytoplankton, including cyanobacteria, and interpreting whether changes observed are likely to be responses to the interventions, or whether they are due to normal fluctuations or other changes in the ecosystem. While assessing changes in cyanobacterial density alone will indicate success or failure, it misses providing an in-depth understanding of the mechanisms leading to any observed changes, and therefore, zooplankton data are also important. Willmitzer (2010) showed a simple approach to validating whether planktivorous fish have been sufficiently reduced to allow zooplankton to reduce phytoplankton via biofiltration, that is, through monitoring the presence of large zooplankton, particularly Daphnia ("water fleas") which have high filtration rates. For this, the proportion of large and small zooplankton is a useful indicator (CSI=Cladocera Size Index), and for this purpose, sampling with simple plankton net hauls with large and small mesh sizes is sufficient. Evaluation of the zooplankton does not need to be taxonomically rigorous, as the data needed are size distribution rather than species. However, this does not necessarily indicate whether or not the large Daphnia are able to exert sufficient grazing pressure upon the cyanobacterial species responsible for the bloom, because many bloom species are indeed poorly edible.

Validating the success of fish stock management is therefore most effective through a comprehensive limnological assessment of the aquatic ecosystem on the basis of quantifying both cyanobacteria and zooplankton conducted sufficiently often. While fish stock studies are needed at intervals of several years, plankton usually needs to be monitored at least monthly. Misinterpretations include that where the necessary limnological expertise and/or data on the prior condition of the waterbody were lacking, seasonal fluctuations like spring clearwater phases (typical for many temperate lakes and reservoirs) have been misinterpreted as success of measures. 


\subsubsection{Enhancing competition of macrophytes against cyanobacteria}

The introduction of macrophytes (totally or partially submerged aquatic plants) has the greatest chance of success in waterbodies with a relatively large shallow littoral area of lakes. Macrophytes are mostly unable to colonise reservoirs with pronounced fluctuations of water level. Submerged macrophytes also require relatively high light penetration, and therefore, introducing them works best at moderate concentrations of total phosphorus (TP), that is, less than $50 \mu \mathrm{g} / \mathrm{L}$. This is because under field conditions, $1 \mu \mathrm{g}$ of TP can support about $1 \mu \mathrm{g}$ of chlorophyll- $a$ (see sections 4.3.2 and 4.4), and if the spring phytoplankton reaches a biomass containing $50-100 \mu \mathrm{g} / \mathrm{L}$ of chlorophyll, this renders the water very turbid, thus suppressing the growth of submerged macrophytes. In contrast, if it is nutrient-limited and therefore clearer, macrophytes have an increased chance to begin to grow. If further nutrient loads during summer are not too high, they can then incorporate enough of the available phosphorus with their growth to achieve substantial phosphorus limitation of phytoplankton biomass for the remaining growing season. Thus, measures to support macrophytes may switch a slightly eutrophic aquatic ecosystem particularly a shallow one with large areas covered by macrophytes - into a different, potentially more stable aquatic community, resulting in clear water and low cyanobacterial biomass. This effect can be enhanced by also managing fish stock, as discussed above.

Excessive nutrient concentrations tend to be detrimental to aquatic macrophytes: for example, a comprehensive study based upon 97 shallow lakes on the Yangtze Plain, China, found that macrophytes begin to collapse and degrade when the TP concentration increased to more than $60-80 \mu \mathrm{g} / \mathrm{L}$, and the authors suggest that the collapse of particular macrophyte species can serve as an early warning signal for the regime shifts from clear to turbid state with increasing phosphorus levels (Su et al., 2019). While Jeppesen et al. (2007b) suggested the growth of submerged aquatic plants to diminish if nitrogen concentrations were above 1000-2000 $\mu \mathrm{g} / \mathrm{L}$, Søndergard et al. (2015) showed this to be relevant only if TP concentrations are also high $(>100 \mu \mathrm{g} / \mathrm{L})$ and that for numerous lakes in Denmark, reducing TP has been more effective in promoting re-colonisation with macrophytes than reducing only $\mathrm{N}$ (see discussion in Chorus and Spijkerman, 2020).

Where boat traffic damages reed belts both, directly and through wave action, protecting the reed belt may be a further measure to foster macrophytes as competitors against cyanobacteria. This can be achieved by constructing structures (e.g., wooden palisades) in the water at a depth of about $2 \mathrm{~m}$ in front of the remnants of reed stands or newly planted ones. Such structures should reach about $50 \mathrm{~cm}$ above the water surface in order to effectively intercept even larger waves. They can be occasionally interrupted by small gaps to allow water birds to move between the lake and the 
quiescent protected water behind the structures. Where recreational use pressure on a lake shore is high, protecting the reed belt with a fence on its landward side may also be important to prevent erosion and mechanical damage and to allow recovery.

\section{CHECKLIST 8.I5: ASSESSING THE PROSPECT OF SUCCESS FOR BIOLOGICAL CONTROL OF CYANOBACTERIA THROUGH INTRODUCING OR SUPPORTING MACROPHYTES}

- Have existing macrophyte stands been assessed, particularly in spring?

- Does the waterbody have large shallow areas that could potentially harbour major macrophyte stands?

- Are concentrations of total phosphorus (TP) usually below 50-100 $\mu \mathrm{g} / \mathrm{L}$, so that there is a chance of sufficient $\mathrm{P}$ reduction by $\mathrm{P}$ binding in macrophyte stands?

- Are reasons for poor macrophyte development understood or at least working hypotheses available that merit testing?

- Would macrophytes freshly introduced into the waterbody have a fair chance of developing, or is the water too turbid or recreational pressure on shorelines too high?

- Are shorelines protected from wave erosion and plant shoots likely to be sufficiently protected from bird grazing?

\section{Operational monitoring of enhancing competition against cyanobacteria by introducing or supporting macrophytes}

Operational monitoring of macrophyte management measures can be relatively straightforward by regular reviews of measures for introducing macrophytes, by observing macrophyte growth and/or by inspecting the integrity of structures to protect, for example, reed belts.

\section{Validation of enhancing competition against cyanobacteria by introducing or supporting macrophytes}

Whether macrophytes successfully compete against cyanobacteria can be readily validated by observation and recording the sediment area covered by macrophytes as well as visual indicators of cyanobacterial blooms, that is, a decrease in turbidity and scum occurrence. Additionally, a limnological monitoring programme involving reductions in concentrations of TP 
and cyanobacterial biomass as well as an increase in water transparency is useful to obtain a better in-depth understanding of the mechanisms determining success or failure.

Surveying the increase of macrophyte stands can be conducted on an annual basis and thus requires low frequency monitoring. In contrast, as for validating biomanipulation through managing the fish stock (section 8.7.1), monitoring of transparency, cyanobacterial biomass and concentrations of total phosphorus needs to be conducted sufficiently often to be able to distinguish between success of the measure and natural fluctuations or those due to other changes in the system - that is, at intervals of weekly to monthly. In both cases, several years of observation will be necessary to assess success or failure.

\subsection{INTRODUCING BARLEY STRAW}

The effect of rotting or decomposing barley straw in reducing the growth of algae was first demonstrated by Welch et al. (1990) who showed the reduction of the growth of green filamentous algae, Cladophora glomerata, in a canal. Since then, the use of decomposing barley straw for the control of algae and cyanobacteria has been the subject of considerable interest and investigation, with numerous publications showing some effect. Numerous other studies have not supported barley straw's algicidal activity. It has been even suggested that anaerobic decomposition of straw produces chemicals which actually stimulate the growth of algae, because the algae can use them as a source of carbon (Martin \& Ridge, 1999; Terlizzi et al., 2002).

Mechanisms postulated include the production of antibiotics by fungal flora or the release of phenolic compounds such as ferulic acid and $p$-coumaric acid from the decomposition of straw cell walls (Newman \& Barrett, 1993); the possibility that the straw acts as a carbon source for carbon limited microbial growth which then uses available phosphorus preventing its use by cyanobacteria (Anhorn, 2005); compounds that chelate with essential metals, thus making them unavailable (Geiger et al., 2005); or antialgal activity of fungi present in the straw (Pillinger et al., 1992). Other studies have indicated a large number and range of compounds, including phenolic, quinone compounds and flavolignans, extracted from straw to have a significant cyanocidal toxicity (Murray et al., 2010; Xiao et al., 2014). One of the first theories proposed for cyanocidal action of barley straw was the generation of hydrogen peroxide during photooxidation of constituents in the straw (Everall \& Lees, 1997). Iredale et al. (2012) confirmed that hydrogen peroxide does form during decomposition, but many variables may determine its cyanocidal effects, including the cyanobacterial strains treated, the amount of UV-supplemented visible light, the temperature and the form of straw used and its state of decomposition. The activity of barley 
straw is usually described as being algaestatic (prevents new growth of algae) rather than algicidal (kills already existing algae).

The contradictory findings, the inconclusive understanding of the mechanisms where effects have been observed and the unknown identity of the potentially phytotoxic compound(s) in rotting barley straw indicate that this technique is still too poorly understood to recommend it for widespread use as a measure to control cyanobacteria, particularly for potable water supply.

\subsection{CHEMICAL CONTROL OF CYANOBACTERIA}

Algicides have been used rather widely in some regions to rapidly eliminate cyanobacterial bloom outbreaks, to avoid cyanotoxins as well as off-flavour problems caused by cyanobacteria. Algicide treatment has been proposed as being more cost-effective than toxin and/or off-flavour removal in drinking-water treatment, because an extended period of persistent blooms greatly enhances the need for additional treatment for removal of dissolved organic carbon, off-flavours and toxins. Environmental concerns have been raised, also because the most commonly used algicide, copper sulphate, has broad ecological impact and the copper may accumulate in the lake sediments (Prepas \& Murphy, 1988). Copper and other heavy metals differ from some other toxic contaminants in that they are not biodegradable, and once they have entered the environment, their potential toxicity is controlled largely by their speciation or physicochemical form (Florence, 1982; Mastin \& Rodgers, 2000).

These concerns tend to limit algicide treatment to special circumstances for reservoirs relevant for water supply, as an emergency measure applied at one point in time, particularly where alternative drinking-water sources are not available and preventive measures are not feasible or not yet effective. As a long-term solution, algicide treatment is unsatisfactory, and wherever possible, control measures which address the factors that promote cyanobacteria are preferable. In many countries, national or local environmental regulations prohibit or limit the use of algicides because of their adverse environmental impact. Legal requirements therefore need to be clarified prior to considering the use of algicides.

A major limitation of any agent which disrupts cyanobacterial cells is the release of toxins and of taste and odour compounds from the cells to which they are normally confined (Lahti et al., 1996). Toxin release upon treatment can be quite rapid, and different studies have shown it to occur within 3-24h (Kenefick et al., 1993; Jones \& Orr, 1994). These dissolved toxins will then disperse and be diluted throughout the waterbody, and they may not be removed by conventional flocculation and filtration procedures in drinking-water treatment. Installation of additional treatment for removing dissolved cyanotoxins may be costly. The risk of treating dense 
blooms with algicides was demonstrated in an incident which occurred on tropical Palm Island, Australia, where members of the community became ill with hepato-enteritis following treatment of a bloom in the water supply reservoir with copper sulphate (Bourke et al., 1983) (see Box 5.3). If algicide treatment is used, this is therefore better done early at the beginning of bloom development to prevent further cyanobacterial growth (Cameron, 1989), thus limiting the amount of toxin that can be released.

Algicides, like all management techniques, must be applied correctly to work effectively. Application at the early stages of bloom development when cell densities are low not only reduces the potential for liberation of intracellular toxin but also will enhance the effectiveness of treatment because cyanobacterial cells can form a major part of the copper demand along with other organic matter in natural water.

If algicides are used to control toxic cyanobacteria, the reservoir should be isolated from the drinking-water supply for a sufficiently long time period to allow the toxins and odours to degrade. Unfortunately, very little data exist on the withholding period in relation to toxin loss specifically after algicide treatment. However, as discussed in general for biodegradation of microcystins in section 2.1, these cyanotoxins are likely to be degraded within a few days if conditions are favourable. However, this needs to be checked on site, as an early study of Jones et al. (1994) showed degradation after algicide treatment took more than 14 days. Furthermore, cylindrospermopsin appears to be particularly poorly biodegradable (section 2.2 ).

In some cases, algicide treatment may be unsuccessful or only partially successful. This can be due to inadequate dispersal and contact with the target organisms, variable sensitivity of cyanobacteria, and reduced efficacy due to complexation of the copper (Burch et al., 1998). The form of copper compound which is most bioavailable and toxic to aquatic organisms is influenced by $\mathrm{pH}$, organic carbon, alkalinity, ionic strength or conductivity (McKnight et al., 1983; Mastin \& Rodgers, 2000).

\subsection{Copper sulphate}

Records of the use of copper sulphate date from 1890 in Europe (Sawyer \& Hazzard, 1962), from 1904 in the USA (Moore \& Kellerman, 1905) and at least back to the mid-1940s in Australia (Burch et al., 1998). Copper sulphate has been regarded as the algicide of choice because it is economic, effective, relatively safe and easy to apply. It is also considered to be of limited significance to human health at the doses commonly used (WHO, 2017) and has been considered not to cause extensive environmental damage (Elder \& Horne, 1978; McKnight et al., 1983). The latter point has been an issue of debate for some time (see Mackenthun \& Cooley, 1952) because of the abovementioned tendency of copper to accumulate in lake sediments (Hanson \& Stefan, 1984). In some cases, it appears not to be 
remobilised and is bound permanently to the sediments (Elder \& Horne, 1978). However, in a study of 10 drinking-water dugouts (small reservoirs) in Canada, sediment copper (previously accumulated from copper sulphate treatments) was released back into the open water under conditions of low dissolved oxygen in the hypolimnion in summer (Prepas \& Murphy, 1988). It has also been suggested that sediment-bound copper could have an impact on the benthic macroinvertebrate community (Hanson \& Stefan, 1984).

The effect of copper as an algicide is generally short-lived due to rapid loss via precipitation as insoluble salts and hydroxylates, depending upon the chemical conditions in the receiving water (Cooke et al., 1993; Fan et al., 2013). Copper sulphate treatment has been shown to cause short-term changes in phytoplankton abundance and species succession (Effler et al., 1980; McKnight, 1981). An additional consideration is that the chronic application of copper algicides may encourage cyanobacteria to become resistant to it, and it thus may cause shifts in the composition of the phytoplankton community with prevalence of copper-resistant green algae (Qian et al., 2010; Rouco et al., 2014). Fish kill has also been reported following copper sulphate treatment, although it is not clear whether this was a result of copper toxicity or oxygen depletion caused by the decaying bloom (Hanson \& Stefan, 1984).

\subsubsection{Copper chelates}

Chelated copper algicides were developed to overcome the problems of the complexation and precipitation loss of toxic copper and thus reduced effectiveness of copper sulphate treatment in hard alkaline water. The different copper formulations include copper oxychloride, organocopper complexes like copper ethanolamine complex or copper citrate used in commercial preparations (Murray-Gulde et al., 2002; Calomeni et al., 2014). The effectiveness of these formulations depends upon a range of factors, including both the target organism and the effect of chemical conditions in the water on bioavailability and toxicity (Mastin \& Rodgers, 2000; Calomeni et al., 2014).

\subsubsection{Hydrogen Peroxide}

A range of both stabilised compounds and liquid hydrogen peroxide $\left(\mathrm{H}_{2} \mathrm{O}_{2}\right)$ have been developed and used more recently in a desire to overcome the environmental issues associated with copper algicides (Matthijs et al., 2016). Hydrogen peroxide is a strong candidate due to its apparently selective toxicity to cyanobacteria combined with the rapid degradation of the chemical to water and oxygen with no residual. Matthijs et al. (2016) describe it as potentially a more specific and sustainable "cyanocide" compared to copper chemicals, herbicides, natural compounds from plant extracts (e.g., barley straw) and other organic chemicals compared for cyanobacterial control. 
The effects of hydrogen peroxide on photosynthesis are reported to be relatively rapid - that is, within 3-5 h (Matthijs et al., 2016), and loss of membrane integrity with some evidence of release of cyanotoxins follows over several days after treatment (Matthijs et al., 2012; Lürling et al., 2014). Cyanobacteria appear to be more sensitive to hydrogen peroxide than eukaryotic algae as they do not possess the defensive enzyme and substrate mechanisms of green algae to convert reactive oxygen species and to neutralise their toxic effects upon photosynthesis and subsequent growth of cells (Drábková et al., 2007a; Drábková et al., 2007b). This mechanism and mode of action as a specific cyanocide has been tested successfully in both the laboratory (Drábková et al., 2007a; Weenink et al., 2015) and in the field with natural phytoplankton populations (Matthijs et al., 2012). Hydrogen peroxide has been applied in a range of lakes, and the effective dose rates for control of cyanobacteria vary widely from $<5 \mathrm{mg} / \mathrm{L}$ up to 100 $\mathrm{mg} / \mathrm{L}$. They depend upon the target strain type and its density and also on the presence of eukaryotic algae. While in the Netherlands the dose is restricted to $<5 \mathrm{mg} / \mathrm{L}$ to avoid killing non-target species, concentrations in the higher end of the range may be required for colony-forming taxa such as Microcystis aeruginosa, where mucilage may protect cells against the oxidising effects of $\mathrm{H}_{2} \mathrm{O}_{2}$ (Lürling \& Tolman, 2014b). At the time of publication of this document, adverse and potentially toxic effects of hydrogen peroxide on nontarget organisms in natural treatment situations have not been widely reported. Nonetheless, monitoring the impacts on non-target organisms is advised on a case-by-case basis, particularly when utilising dose rates approaching up to $100 \mathrm{mg} / \mathrm{L}$.

Addressing the questions in Checklist 8.16 will help decide whether to apply algicide treatment. If this is intended, choosing the best method for the respective waterbody will require expertise particularly in aquatic ecology and limnology and a good understanding of the waterbody's chemical condition and biota.

\section{CHECKLIST 8.16: ASSESSING THE BENEFITS AND THE PROSPECT OF SUCCESS OF CONTROL OF CYANOBACTERIA THROUGH ALGICIDE TREATMENT}

- Have other options been sufficiently assessed, and is algicide treatment the only feasible short-term option?

- Which cyanotoxins are expected to be the predominant problem cell-bound microcystins and neurotoxins or rather cylindrospermopsin with a potentially high extracellular fraction?

- How likely is a low cyanobacterial population to grow into a major bloom? Are data available from the waterbody for previous years - is this a typical pattern for the waterbody? Are nutrient concentrations 
available to infer the carrying capacity for biomass (see section 4.3.2), and is this potentially limiting, so that major blooms are unlikely?

- Will the impact on cyanobacteria and on released toxins be sufficiently monitored to prevent exposure to higher concentrations of dissolved cyanotoxins? How will the cyanobacterial response be monitored?

- If the waterbody is used as drinking-water supply, can it be isolated from the supply until the lysed algal biomass, toxins and possibly occurring off-flavour substances have degraded? How long is this expected to take and what criterion will be used as basis for the decision to take the waterbody back into the drinking-water supply (e.g., concentrations of dissolved organic carbon (DOC) or cyanotoxin)?

- If the waterbody remains online for drinking-water supply, is treatment available to remove dissolved toxins, and how will it respond to the challenge of the DOC pulse expected from algicide treatment?

- Which algicide will be used (see below), what dose is necessary, how will it be applied and at which time interval is repeated treatment likely to be necessary?

- Is the chosen algicide likely to be sufficiently effective in the specific water (e.g., copper may be less effective in waters with high dissolved carbonate or at alkaline $\mathrm{pH}$ ) at the dosing regime planned?

- Is algicide treatment compliant with local regulations?

- Do further stakeholders need to be involved (e.g., environmental and health authorities, water boards)?

\section{Operational monitoring of chemical control of cyanobacteria}

Operational monitoring will check whether chemicals are dosed as planned, whether they reach the target concentration in the waterbody and whether measures to protect humans (like isolating the reservoir from a drinkingwater supply until dissolved toxins have been degraded) are in place.

Validation of chemical control of cyanobacteria

Validation of plans for chemical control best begins with reviewing whether these measures are necessary or whether other options are available that should be tested first. It will then review whether the intended chemical cyanobacterial control measure is likely to be effective and feasible for the specific waterbody and its specific blooms, whether potentially detrimental impacts on other biota can be accepted and whether human exposure to dissolved toxins can effectively be prevented. This typically needs expertise in phytoplankton ecology and waterbody management, but also an understanding of water chemistry. Post-treatment monitoring should include the 
development of the biota to both ensure the efficacy of treatment and better understand the ecological effects. In addition, analyses of dissolved cyanotoxins should be included where drinking-water is being abstracted.

In the interest of long-term sustainability, it is advisable to initiate the implementation of other controls which are more sustainable than algicide treatment, even if these measures are effective only in the longer term - that is, the reduction of nutrient loads and/or internal measures as discussed above.

\subsection{ULTRASONICATION FOR CONTROL OF CYANOBACTERIA}

The use of ultrasound for the control of cyanobacteria in both freshwater and wastewater storages has long been proposed as a non-chemical technique and thus as an attractive prospect. It has also become popular across a range of countries since about the turn of the millennium, due to the availability and promotion of relatively low-cost commercial ultrasound systems for cyanobacterial control. Ultrasound is sound energy with frequencies that are higher than can be detected by the human ear (i.e., approximately $>20 \mathrm{kHz}$ ). It has been reported to reduce cyanobacterial growth through a range of mechanisms that affect the structural integrity of cells (membrane damage or gas vesicle collapse and destruction) or impact cell physiology (photosynthetic activity and growth reduction; Wu et al., 2011; Rajasekhar et al., 2012; Park et al., 2017).

A reduction in cyanobacterial growth through the application of sound energy to cells and colonies is likely to be due to a combination of many effects and will depend upon the target organism, the power or energy applied, the frequency and the design of application of ultrasound. Key operational parameters in the application of ultrasound for algal control are frequency, intensity (or power) and duration of exposure (Park et al., 2017), and the more successful ones among the studies available have been able to explore and optimise these parameters.

Although research results to support the effectiveness and mechanism of action of ultrasound in aquatic systems have been accumulating, objective assessments and comparisons of findings are not straightforward. The studies and reviews of the mechanisms and effectiveness of ultrasound for cyanobacterial control describe a wide range of test conditions applied in the laboratory or field, both with cultures and with natural material (Pavagadhi et al., 2013; Lürling \& Tolman, 2014a; Lürling et al., 2016; Park et al., 2017). Published studies have mostly used custom-made or experimental equipment with a range of frequencies and power intensity which are different to commercially available units. Most of the studies that have shown clear effects upon cyanobacteria have used high-power purpose-built experimental 
devices while the commercial devices sold for algal control are relatively low power (Lürling et al., 2016). The low-energy ultrasound devices are all very similar in design and application; however, they use a range of different ultrasound frequencies in the lower range and various configurations of pumps to circulate water past ultrasonic transducers. The range of conflicting reports from the literature on the effectiveness of ultrasound in natural waterbodies with cyanobacterial contamination is most likely due to difference in both design and configuration of the sonication equipment in relation to the size of the waterbodies. In addition, designing studies to account for confounding ecological effects that influence growth is challenging.

Several examples from the published studies highlight the conflicting results: field trials with ultrasound devices conducted in the Netherlands in 2007 concluded that ultrasound was not effective in reducing cyanobacteria (Kardinaal et al., 2008). Similarly, in the UK, Purcell et al. (2013) tested two models of commercial ultrasound devices with inconsistent results. By contrast, an evaluation of four commercial ultrasound devices in a pair of reservoirs in New Jersey (USA) found positive results (Schneider et al., 2015). A further comprehensive study in the Netherlands based upon both experiments and a critical literature review concluded that the commercially available ultrasound transducers tested would not control cyanobacteria in situ (Lürling et al., 2014).

In conclusion, the application of ultrasound for cyanobacterial control remains under question because of the limited number of both validated field and pilot tests and the lack of information on the feasibility of both commercial and experimental devices for use in larger waterbodies. In particular, a set of criteria for successful application appears to be lacking.

\section{II MEASURES TO CONTROL THE PROLIFERATION OF BENTHIC CYANOBACTERIA}

Mitigation strategies to remove or reduce toxic benthic cyanobacteria are very limited because for the large majority of situations, there is little knowledge about the environmental variables that regulate their proliferation. There are very few reports on the management of benthic cyanobacteria, and anecdotally, they are regarded as more difficult to control or remove (Liu et al., 2019). As discussed in section 4.2.2, benthic cyanobacteria may grow at low nutrient concentrations and be less sensitive to nutrient reduction than phytoplankton (Bonilla et al., 2005), so that nutrient management is less likely to limit their growth. Where nutrients and fine sediment have been implicated as a cause (e.g., McAllister et al., 2016), actions such as planting riparian margins, regulation of fertiliser application in the catchment and preventing stock access to river/streams edges may ultimately reduce proliferation, but this has not been demonstrated. 
In flow-regulated rivers and streams, flushing flows have been used to remove other nuisance periphyton growth, but this is not known to have been successfully applied to cyanobacteria, probably because toxic benthic cyanobacteria have not been reported from rivers or streams where this would be feasible, particularly where they occur naturally even in pristine streams and oligotrophic lakes (see section 4.2.2). Techniques that are recommended for the management of odour-producing benthic cyanobacteria are discussed by Liu et al. (2019), including the application of algicides, physical removal by disturbance treatments and reducing water levels to dry out or desiccate the benthic cyanobacteria. These techniques all have limitations, and the more destructive techniques (algicides and physical removal) may have potential adverse impacts such as lysing cells or dislodging mats which may then release toxins.

Mitigation of the growth of toxic benthic cyanobacteria may neither be practical nor necessary for the target of protecting human health, as they are not known to cause health-relevant toxin concentrations in the surrounding water. Therefore, the most feasible management option may be to provide information on avoiding direct contact with dislodged and floating mats (including preventing pets from coming into contact; see Section 5.2 and Chapter 15).

\section{REFERENCES}

Akhurst D, Jones GB, McConchie DM (2004). The application of sediment capping agents on phosphorus speciation and mobility in a sub-tropical dunal lake. Mar Freshwater Res. 55:715-725.

Anhorn R (2005). A study of the water quality of 145 Metropolitan area lakes. Saint Paul (MN): Metropolitan Council:451 pp.

Antenucci JP, Alexander R, Romero J, Imberger J (2003). Management strategies for a eutrophic water supply reservoir - San Roque, Argentina. Wat Sci Technol. 47:149-155.

Baker PD, Brookes JD, Burch MD, Maier HR, Ganf GG (2000). Advection, growth and nutrient status of phytoplankton populations in the lower River Murray, South Australia. Reg Riv Res Man. 16:327-344.

Baldwin DS (1996). The phosphorus composition of a diverse series of Australian sediments. Hydrobiologia. 335:63-73.

Baldwin DS, Mitchell A, Rees G (2000). The effects of in situ drying on sedimentphosphate interactions in sediments from an old wetland. Hydrobiologia. 431:3-12.

Becker A, Herschel A, Wilhelm C (2006). Biological effects of incomplete destratification of hypertrophic freshwater reservoir. Hydrobiologia. 559:85-100.

Bertone E, Burford MA, Hamilton DP (2018). Fluorescence probes for real-time remote cyanobacteria monitoring: a review of challenges and opportunities. Water Res. 141:152-162.

Beutel MW, Horne AJ (1999). A review of the effects of hypolimnetic oxygenation on lake and reservoir water quality. Lake Reserv Manage. 15:285-297. 
Bonilla S, Villeneuve V, Vincent WF (2005). Benthic and planktonic algal communities in a high arctic lake: pigment structure and contrasting responses to nutrient enrichment. J Phycol. 41:1120-1130.

Bormans M, Maršálek B, Jančula D (2016). Controlling internal phosphorus loading in lakes by physical methods to reduce cyanobacterial blooms: a review. Aquat Ecol. 50:407-422.

Bormans M, Webster IT (1997). A mixing criterion for turbid rivers. Environ Modell Softw. 12:329-333.

Boscaini A, Brescancin F, Cerasino L, Fedrigotti C, Fano EA, Salmaso N (2017). Vertical and horizontal distribution of the microcystin producer Planktothrix rubescens (Cyanobacteria) in a small perialpine reservoir. Adv Oceanogr Limnol. 8:208-221.

Bourke A, Hawes R, Neilson A, Stallman N (1983). An outbreak of hepato-enteritis (the Palm Island mystery disease) possibly caused by algal intoxication. Toxicon. 21:45-48.

Burch M, Velzeboer R, Chow C, Stevens H, Bee C, House J (1998). Evaluation of copper algaecides for the control of algae and cyanobacteria. Urban Water Research Association of Australia, Melbourne. Research Report No. 130. pp.

Burford MA, O`Donohue MJ (2006). A comparison of phytoplankton community assemblages in artificially and naturally mixed subtropical water reservoirs. Freshwater Biol. 51:973-982.

Calomeni A, Rodgers JH, Kinley CM (2014). Responses of Planktothrix agardhii and Pseudokirchneriella subcapitata to Copper Sulfate $\left(\mathrm{CuSO}_{4} \cdot 5 \mathrm{H}_{2} \mathrm{O}\right)$ and a Chelated Copper Compound (Cutrine ${ }^{\circledR}{ }^{-}$-Ultra). Water Air Soil Poll. 225:2231.

Cameron CD (1989). Is this a way to run a reservoir? In: Practical lake management for water quality control. Denver (CO): American Water Works Association:63-83.

Caraco N, Cole J, Strayer D (2006). Top down control from the bottom: regulation of eutrophication in a large river by benthic grazing. Limnol Oceanogr. 51:664-670.

Carpenter SR, Kitchell JF (1996). The trophic cascade in lakes. Cambridge, UK: Cambridge University Press:400 pp.

Chorus I, Schauser I (2011). Oligotrophication of Lake Tegel and Schlachtensee, Berlin-Analysis of system components, causalities and response thresholds compared to responses of other waterbodies. Dessau: Umweltbundesamt:157 pp.

Chorus I, Spijkerman E (2020). What Colin Reynolds could tell us about nutrient limitation, N: P ratios and eutrophication control. Hydrobiologia. 1-17.

Cooke GD, Welch EB, Peterson SA, Newroth PR (1993). Artificial circulation. In: Cooke GD, Welch EB, Peterson SA et al., editors: Restoration and management of lakes and reservoirs. Boca Raton (FL): CRC press:419-449.

Cooke GD, Welch EB, Peterson S, Nichols SA (2005). Restoration and management of lakes and reservoirs. Boca Raton (FL): CRC press:616 pp.

Cowell BC, Dawes CJ, Gardiner WE, Scheda SM (1987). The influence of whole lake aeration on the limnology of a hypereutrophic lake in central Florida. Hydrobiologia. 148:3-24.

DeMelo R, France R, McQueen DJ (1992). Biomanipulation: hit or myth? Limnol Oceanogr. 37:192-207.

Dokulil MT (1994). Environmental control of phytoplankton productivity in turbulent turbid systems. In: Descy JP, Reynolds CS, Padisák J, editors: Phytoplankton in turbid environments: rivers and shallow lakes. Dordrecht: Kluwer Academic Publishers:65-72. 
Douglas G, Hamilton D, Robb M, Pan G, Spears B, Lurling M (2016). Guiding principles for the development and application of solid-phase phosphorus adsorbents for freshwater ecosystems. Aquat Ecol. 50:385-405.

Drábková M, Admiraal W, Maršálek B (2007a). Combined exposure to hydrogen peroxide and light selective effects on cyanobacteria, green algae, and diatoms. Environ Sci Technol. 41:309-314.

Drábková M, Matthijs H, Admiraal W, Maršálek B (2007b). Selective effects of $\mathrm{H}_{2} \mathrm{O}_{2}$ on cyanobacterial photosynthesis. Photosynthetica. 45:363-369.

Effler S, Litten S, Field S, Tong-Ngork T, Hale F, Meyer M et al. (1980). Whole lake responses to low level copper sulfate treatment. Water Res. 14:1489-1499.

Elder JF, Horne AJ (1978). Copper cycles and $\mathrm{CuSO}_{4}$ algicidal capacity in two California lakes. Environ Manage. 2:17-30.

Everall N, Lees D (1997). The identification and significance of chemicals released from decomposing barley straw during reservoir algal control. Water Res. 31:614-620.

Fan J, Ho L, Hobson P, Brookes J (2013). Evaluating the effectiveness of copper sulphate, chlorine, potassium permanganate, hydrogen peroxide and ozone on cyanobacterial cell integrity. Water Res. 47:5153-5164.

Florence T (1982). The speciation of trace elements in waters. Talanta. 29:345-364.

Gächter R (1976). Die Tiefenwasserableitung, ein Weg zur Sanierung von Seen. Schweizerische Zeitschrift für Hydrologie. 38:1-28.

Gächter R, Müller B (2003). Why the phosphorus retention of lakes does not necessarily depend on the oxygen supply to their sediment surface. Limnol Oceanogr. 48:929-933.

Gächter R, Wehrli B (1998). Ten years of artificial mixing and oxygenation: no effect on the internal phosphorus loading of two eutrophic lakes. Environ Sci Technol. 32:3659-3665.

Gantzer PA, Bryant LD, Little JC (2009). Controlling soluble iron and manganese in a water-supply reservoir using hypolimnetic oxygenation. Water Res. 43:1285-1294.

Gardner WS, Nalepa TF, Quigley MA, Malczyk JM (1981). Release of phosphorus by certain benthic invertebrates. Can J Fish Aquat Sci. 38:978-981.

Geiger N, Gearheart R, Henry E, Rueter J, Pan Y (2005). Preliminary research on Aphanizomenon flos-aquae at Upper Klamath Lake, Oregon. Klamath Falls (OR): Klamath Falls Fish and Wildlife Office:158 pp.

Hamilton DP, Salmaso N, Paerl HW (2016). Mitigating harmful cyanobacterial blooms: strategies for control of nitrogen and phosphorus loads. Aquat Ecol. 50:351-366.

Hanson MJ, Stefan HG (1984). Side effects of 58 years of copper sulfate treatment of the Fairmont Lakes, Minnesota. J Am Water Resour Ass. 20:889-900.

Hart BT, Roberts S, James R, O‘Donohue M, Taylor J, Donnert D et al. (2003). Active barriers to reduce phosphorus release from sediments: effectiveness of three forms of $\mathrm{CaCO}_{3}$. Aust J Chem. 56:207-217.

Hawkins P, Griffiths D (1993). Artificial destratification of a small tropical reservoir: effects upon the phytoplankton. Hydrobiologia. 254:169-181.

Heo W-M, Kim B (2004). The effect of artificial destratification on phytoplankton in a reservoir. Hydrobiologia. 524:229-239.

Hölker F, Vanni MJ, Kuiper JJ, Meile C, Grossart H-P, Stief P et al. (2015). Tubedwelling invertebrates: tiny ecosystem engineers have large effects in lake ecosystems. Ecol Monogr. 85:333-351. 
Hrbáček J, Desortova B, Popovský J (1978). Influence of the fishstock on the phosphorus-chlorophyll ratio. Verh Int Ver Limnol. 20:1624-1628.

Huisman J, Sharples J, Stroom JM, Visser PM, Kardinaal WEA, Verspagen JM et al. (2004). Changes in turbulent mixing shift competition for light between phytoplankton species. Ecology. 85:2960-2970.

Hupfer M, Lewandowski J (2008). Oxygen controls the phosphorus release from lake sediments - a long-lasting paradigm in limnology. Int Rev Hydrobiol. 93:415-432.

Ibelings BW, Portielje R, Lammens EH, Noordhuis R, van den Berg MS, Joosse W et al. (2007). Resilience of alternative stable states during the recovery of shallow lakes from eutrophication: Lake Veluwe as a case study. Ecosystems. 10:4-16.

Iredale RS, McDonald AT, Adams DG (2012). A series of experiments aimed at clarifying the mode of action of barley straw in cyanobacterial growth control. Water Res. 46:6095-6103.

Ismail R, Kassim M, Inman M, Baharim N, Azman S (2002). Removal of iron and manganese by artificial destratification in a tropical climate (Upper Layang Reservoir, Malaysia). Wat Sci Technol. 46:179-183.

Jeppesen E, Meerhoff M, Jacobsen B, Hansen R, Søndergaard M, Jensen J et al. (2007a). Restoration of shallow lakes by nutrient control and biomanipulation-the successful strategy varies with lake size and climate. Hydrobiologia. 581:269-285.

Jeppesen E, Søndergaard M, Meerhoff M, Lauridsen TL, Jensen JP (2007b). Shallow lake restoration by nutrient loading reduction-some recent findings and challenges ahead. Hydrobiologia. 584:239-252.

Jones GJ, Bourne DG, Blakeley RL, Doelle H (1994). Degradation of cyanobacterial hepatotoxin microcystin by aquatic bacteria. Nat Toxins. 2:228-235.

Jones GJ, Orr PT (1994). Release and degradation of microcystin following algicide treatment of a Microcystis aeruginosa bloom in a recreational lake, as determined by HPLC and protein phosphatase inhibition assay. Water Res. 28:871-876.

Kardinaal E, De Haan M, Ruiter H (2008). Maatregelen ter voorkoming blauwalgen werken onvoldoende. $\mathrm{H}_{2} \mathrm{O}$. 41:4-7.

Kenefick SL, Hrudey SE, Peterson HG, Prepas EE (1993). Toxin release from Microcystis aeruginosa after chemical treatment. Wat Sci Technol. 27:433-440.

Kitchell JF (1992). Food web management: a case study of Lake Mendota. New York: Springer:556 pp.

Kolzau S, Wiedner C, Rücker J, Köhler J, Köhler A, Dolman AM (2014). Seasonal patterns of nitrogen and phosphorus limitation in four German lakes and the predictability of limitation status from ambient nutrient concentrations. PLoS One. 9:e96065.

Lahti K, Kilponen J, Kivimaeki A (1996). Removal of cyanobacteria and their hepatotoxins from raw water in soil and sediment columns. In: Kivimki A-L, Suokko T, editors: Artificial recharge of groundwater NHP/Report No 38. Helsinki:187-195.

Lewis DM (2004). Surface mixers for destratification and management of Anabaena circinalis. School of Civil and Environmental Engineering, University of Adelaide:249 pp.

Liu Z, Lin T-F, Burch M (2019). Management of T\&O in source water. In: Lin T-F, Watson S, Dietrich AM et al., editors: Taste and odour in source and drinking water: causes, controls, and consequences. London: International Water Association:304.

Lürling M, Meng D, Faassen EJ (2014). Effects of hydrogen peroxide and ultrasound on biomass reduction and toxin release in the cyanobacterium, Microcystis aeruginosa. Toxins. 6:3260-3280. 
Lürling M, Tolman Y (2014a). Beating the blues: is there any music in fighting cyanobacteria with ultrasound? Water Res. 66:361-373.

Lürling M, Tolman Y (2014b). Effects of commercially available ultrasound on the zooplankton grazer Daphnia and consequent water greening in laboratory experiments. Water. 6:3247-3263.

Lürling M, Waajen G, de Senerpont Domis LN (2016). Evaluation of several endof-pipe measures proposed to control cyanobacteria. Aquat Ecol. 50:499-519.

Mackenthun K, Cooley H (1952). The biological effect of copper sulphate treatment on lake ecology. Trans Wisconsin Acad Sci, Arts Lett. 41:177-187.

Maier HR, Kingston GB, Clark T, Frazer A, Sanderson A (2004). Risk-based approach for assessing the effectiveness of flow management in controlling cyanobacterial blooms in rivers. Riv Res Appl. 20:459-471.

Martin D, Ridge I (1999). The relative sensitivity of algae to decomposing barley straw. J Appl Phycol. 11:285-291.

Mastin B, Rodgers J (2000). Toxicity and bioavailability of copper herbicides (Clearigate, Cutrine-Plus, and copper sulfate) to freshwater animals. Arch Environ Contam Toxicol. 39:445-451.

Matthijs HC, Jančula D, Visser PM, Maršálek B (2016). Existing and emerging cyanocidal compounds: new perspectives for cyanobacterial bloom mitigation. Aquat Ecol. 50:443-460.

Matthijs HC, Visser PM, Reeze B, Meeuse J, Slot PC, Wijn G et al. (2012). Selective suppression of harmful cyanobacteria in an entire lake with hydrogen peroxide. Water Res. 46:1460-1472.

McAllister TG, Wood SA, Hawes I (2016). The rise of toxic benthic Phormidium proliferations: a review of their taxonomy, distribution, toxin content and factors regulating prevalence and increased severity. Harmful Algae. 55:282-294.

McAuliffe T, Rosich RS (1989). Review of artificial destratification of water storages in Australia. Water Research Association of Australia, Sydney. Research Report No. 9.233 pp.

McKnight D (1981). Chemical and biological processes controlling the response of a freshwater ecosystem to copper stress: a field study of the $\mathrm{CuSO}_{4}$ treatment of Mill Pond Reservoir, Burlington, Massachusetts. Limnol Oceanogr. 26:518-531.

McKnight DM, Chisholm SW, Harleman DR (1983). CuSO ${ }_{4}$ treatment of nuisance algal blooms in drinking water reservoirs. Environ Manage. 7:311-320.

Mitchell A, Baldwin DS (1998). Effects of desiccation/oxidation on the potential for bacterially mediated P release from sediments. Limnol Oceanogr. 43:481-487.

Moore BC, Cross BK, Clegg EM, Lanouette BP, Skinner M, Preece E et al. (2014). Hypolimnetic oxygenation in Twin Lakes, WA. Part I: distribution and movement of trout. Lake Reserv Manage. 30:226-239.

Moore GT, Kellerman KF (1905). Copper as an algicide and disinfectant in water supplies. US Government Printing Office. Bulletin Nr. 76.55 pp.

Moss B, Kosten S, Meerhoff M, Battarbee RW, Jeppesen E, Mazzeo N et al. (2011). Allied attack: climate change and eutrophication. Inland Waters. 1:101-105.

Moss B, McGowan S, Carvalho L (1994). Determination of phytoplankton crops by top-down and bottom-up mechanisms in a group of English lakes, the West Midland meres. Limnol Oceanogr. 39:1020-1029. 
Murphy T, Prepas EE (1990). Lime treatment of hardwater lakes to reduce eutrophication. Verh Int Ver Limnol. 24:327-334.

Murray D, Jefferson B, Jarvis P, Parsons S (2010). Inhibition of three algae species using chemicals released from barley straw. Environ Technol. 31:455-466.

Murray-Gulde C, Heatley J, Schwartzman A, Rodgers Jr J (2002). Algicidal effectiveness of clearigate, cutrine-plus, and copper sulfate and margins of safety associated with their use. Arch Environ Contam Toxicol. 43:19-27.

Newman JR, Barrett P (1993). Control of Microcystis aeruginosa by decomposing barley straw. J Aquat Plant Manage. 31:203.

Nürnberg GK (1997). Coping with water quality problems due to hypolimnetic anoxia in Central Ontario Lakes. Water Qual Res J Can. 32:391-405.

Nürnberg GK (2007). Lake responses to long-term hypolimnetic withdrawal treatments. Lake Reserv Manage. 23:388-409.

Nürnberg GK, LaZerte BD, Olding DD (2003). An artificially induced Planktothrix rubescens surface bloom in a small kettle lake in Southern Ontario compared to blooms world-wide. Lake Reserv Manage. 19:307-322.

Olszewski P (1961). Versuch einer Ableitung des hypolimnischen Wassers an einem See. Ergebnisse des ersten Versuchsjahres. Verh Int Ver Limnol. 18:1792-1797.

Orihel DM, Baulch HM, Casson NJ, North RL, Parsons CT, Seckar DC et al. (2017). Internal phosphorus loading in Canadian fresh waters: a critical review and data analysis. Can J Fish Aquat Sci. 74:2005-2029.

Park J, Church J, Son Y, Kim K-T, Lee WH (2017). Recent advances in ultrasonic treatment: challenges and field applications for controlling harmful algal blooms (HABs). Ultrason Sonochem. 38:326-334.

Pavagadhi S, Tang ALL, Sathishkumar M, Loh KP, Balasubramanian R (2013). Removal of microcystin-LR and microcystin-RR by graphene oxide: adsorption and kinetic experiments. Water Res. 47:4621-4629.

Pillinger J, Cooper J, Ridges I, Barrett P (1992). Barley straw as an inhibitor of algal growth III: the role of fungal decomposition. J Appl Phycol. 4:353-355.

Prepas E, Murphy T (1988). Sediment-water interactions in farm dugouts previously treated with copper sulfate. Lake Reserv Manage. 4:161-168.

Prepas E, Murphy T, Dinsmore W, Burke J, Chambers P, Reedyk S (1997). Lake management based on lime application and hypolimnetic oxygenation: the experience in eutrophic hardwater lakes in Alberta. Water Qual Res J Can. 32:273-294.

Psenner R, Pucsko R, Sager M (1984). Die Fraktionierung organischer und anorganischer Phosphorverbindungen von Sedimenten-Versuch einer Definition ökologisch wichtiger Fraktionen. Arch Hydrobiol Suppl. 70:111-155.

Purcell D, Parsons SA, Jefferson B, Holden S, Campbell A, Wallen A et al. (2013). Experiences of algal bloom control using green solutions barley straw and ultrasound, an industry perspective. Water Environ J. 27:148-156.

Qian H, Yu S, Sun Z, Xie X, Liu W, Fu Z (2010). Effects of copper sulfate, hydrogen peroxide and $\mathrm{N}$-phenyl-2-naphthylamine on oxidative stress and the expression of genes involved photosynthesis and microcystin disposition in Microcystis aeruginosa. Aquat Toxicol. 99:405-412.

Rajasekhar P, Fan L, Nguyen T, Roddick FA (2012). A review of the use of sonication to control cyanobacterial blooms. Water Res. 46:4319-4329. 
Raman RK, Arbuckle BR (1989). Long-term destratification in an Illinois Lake. J - Am Water Works Assoc. 81:66-71.

Reeders H, Boers P, Van der Molen D, Helmerhorst T (1998). Cyanobacterial dominance in the lakes Veluwemeer and Wolderwijd, The Netherlands. Wat Sci Technol. 37:85-92.

Reynolds C, Descy J-P, Padisák J (1994). Are phytoplankton dynamics in rivers so different from those in shallow lakes? Hydrobiologia. 289:1-7.

Reynolds C, Wiseman S, Godfrey B, Butterwick C (1983). Some effects of artificial mixing on the dynamics of phytoplankton populations in large limnetic enclosures. J Plankton Res. 5:203-234.

Reynolds CS (1997). Vegetation processes in the pelagic: a model for ecosystem theory. Oldendorf/Luhe: Ecology Institute:371 pp.

Robb M, Greenop B, Goss Z, Douglas G, Adeney J (2003). Application of Phoslock TM, an innovative phosphorus binding clay, to two Western Australian waterways: preliminary findings. Hydrobiologia. 494:237-243.

Ross G, Cloete T (2006). Phoslock ${ }^{\circledR}$ field trial at K'shani Lake Lodge, Hartbeespoort Dam. Pretoria: University of Pretoria:13 pp.

Rouco M, López-Rodas V, González R, Huertas IE, García-Sánchez MJ, Flores-Moya A et al. (2014). The limit of the genetic adaptation to copper in freshwater phytoplankton. Oecologia. 175:1179-1188.

Salmaso N, Boscaini A, Capelli C, Cerasino L (2018). Ongoing ecological shifts in a large lake are driven by climate change and eutrophication: evidences from a three-decade study in Lake Garda. Hydrobiologia. 824:177-195.

Sas H (1989). Lake restoration by nutrient control: expectations, experiences, extrapolations. Sankt Augustin: Academia Verlag Richardz:520 pp.

Sawyer CN, Hazzard AS (1962). Causes, effects, and control of aquatic growths. J Water Pollut Control Fed. 34: 279-290.

Schauser I, Chorus I (2007). Assessment of internal and external lake restoration measures for two Berlin lakes. Lake Reserv Manage. 23:366-376.

Schauser I, Chorus I (2009). Water and phosphorus mass balance of Lake Tegel and Schlachtensee-A modelling approach. Water Res. 43:1788-1800.

Schauser I, Chorus I, Lewandowski J (2006). Effects of nitrate on phosphorus release: comparison of two Berlin lakes. Acta Hydrochim Hydrobiol. 34:325-332.

Scheffer M, Carpenter SR (2003). Catastrophic regime shifts in ecosystems: linking theory to observation. Trends Ecol Evol. 18:648-656.

Scheffer M, Hosper SH, Meijer ML, Moss B, Jeppesen E (1993). Alternative equilibria in shallow lakes. Trends Ecol Evol. 8:275-279.

Scheffer M, Rinaldi S, Gragnani A, Mur LR, van Nes EH (1997). On the dominance of filamentous cyanobacteria in shallow, turbid lakes. Ecology. 78:272-282.

Schladow SG (1993). Lake destratification by bubble-plume systems: design methodology. J Hydraul Eng. 119:350-368.

Schneider OD, Weinrich LA, Brezinski S (2015). Ultrasonic treatment of algae in a New Jersey reservoir. J - Am Water Works Assoc. 107:E533-E542.

Sherman B, Whittington J, Oliver R (2000). The impact of artificial destratification on water quality in Chaffey Reservoir. Arch Hydrobiol Spec Issues Advanc Limnol. 55:15-29.

Singleton VL, Little JC (2006). Designing hypolimnetic aeration and oxygenation systems- a review. Environ Sci Technol. 40:7512-7520. 
Søndergaard M, Jensen JP, Jeppesen E (2003). Role of sediment and internal loading of phosphorus in shallow lakes. Hydrobiologia. 506:135-145.

Søndergaard M, Lauridsen TL, Johansson LS, Jeppesen E (2017). Nitrogen or phosphorus limitation in lakes and its impact on phytoplankton biomass and submerged macrophyte cover. Hydrobiologia 795:35-48.

Su H, Wu Y, Xia W, Yang L, Chen J, Han W et al. (2019). Stoichiometric mechanisms of regime shifts in freshwater ecosystem. Water Res. 149:302-310.

Terlizzi DE, Ferrier MD, Armbrester EA, Anlauf KA (2002). Inhibition of dinoflagellate growth by extracts of barley straw (Hordeum vulgare). J Appl Phycol. 14:275-280.

Triest L, Stiers I, Van Onsem S (2016). Biomanipulation as a nature-based solution to reduce cyanobacterial blooms. Aquat Ecol. 50:461-483.

Tsujimura S (2004). Water management of Lake Yogo targeting internal phosphorus loading. Lakes Reserv Res Manage. 9:171-179.

Upadhyay S, Bierlein KA, Little JC, Burch MD, Elam KP, Brookes JD (2013). Mixing potential of a surface-mounted solar-powered water mixer (SWM) for controlling cyanobacterial blooms. Ecol Eng. 61:245-250.

Visser PM, Ibelings BW, Bormans M, Huisman J (2016). Artificial mixing to control cyanobacterial blooms: a review. Aquat Ecol. 50:423-441.

Visser PM, Ibelings BW, van der Veer B, Koedood J, Mur LR (1996). Artificial mixing prevents nuisance blooms of the cyanobacterium Microcystis aeruginosa in Lake Nieuwe Meer, the Netherlands. Freshwater Biol. 36:435-450.

Weenink EF, Luimstra VM, Schuurmans JM, Van Herk MJ, Visser PM, Matthijs HC (2015). Combatting cyanobacteria with hydrogen peroxide: a laboratory study on the consequences for phytoplankton community and diversity. Front Microbiol. 6:714.

Welch EB, Buckley JA, Bush RM (1972). Dilution as an algal bloom control. J Water Pollut Cont Fed. 44:2245-2265.

Welch I, Barrett P, Gibson M, Ridge I (1990). Barley straw as an inhibitor of algal growth I: studies in the Chesterfield Canal. J Appl Phycol. 2:231-239.

Welker M, Walz N (1998). Can mussels control the plankton in rivers? - A planktological approach applying a Lagrangian sampling strategy. Limnol Oceanogr. 43:753-762.

Whittington J, Sherman B, Green D, Oliver RL (2000). Growth of Ceratium hirundinella in a subtropical Australian reservoir: the role of vertical migration. J Plankton Res. 22:1025-1045.

WHO (2017). Guidelines for drinking-water quality, fourth edition, incorporating the 1st addendum. Geneva: World Health Organization:631 pp. https://www. who.int/publications/i/item/9789241549950

Willmitzer H (2010). Bewertung und Bedeutung der Biofiltration des Zooplanktons zur Verbesserung der Wasserqualität in Talsperren. GWF Wasser Abwasser. 151:1070.

Winder M, Sommer U (2012). Phytoplankton response to a changing climate. Hydrobiologia. 698:1-12.

Wu X, Joyce EM, Mason TJ (2011). The effects of ultrasound on cyanobacteria. Harmful Algae. 10:738-743.

Xiao X, Huang H, Ge Z, Rounge TB, Shi J, Xu X et al. (2014). A pair of chiral flavonolignans as novel anti-cyanobacterial allelochemicals derived from barley straw (Hordeum vulgare): characterization and comparison of their anti-cyanobacterial activities. Environ Microbiol. 16:1238-1251. 
Xie L, Xie P (2002). Long-term (1956-1999) dynamics of phosphorus in a shallow, subtropical Chinese lake with the possible effects of cyanobacterial blooms. Water Res. 36:343-349.

Xie P, Liu J (2001). Practical success of biomanipulation using filter-feeding fish to control cyanobacteria blooms: a synthesis of decades of research and application in a subtropical hypereutrophic lake. Sci World J. 1:337-356.

Zamyadi A, Choo F, Newcombe G, Stuetz R, Henderson RK (2016). A review of monitoring technologies for real-time management of cyanobacteria: recent advances and future direction. Trends Anal Chem. 85:83-96.

Zhang Y, Prepas E (1996). Short-term effects of $\mathrm{Ca}(\mathrm{OH})_{2}$ additions on phytoplankton biomass: a comparison of laboratory and in situ experiments. Water Res. 30:1285-1294. 